\title{
Signal Transduction: From the Atomic Age to the Post-Genomic Era
}

\section{Jeremy Thorner ${ }^{1}$, Tony Hunter ${ }^{2}$, Lewis C. Cantley ${ }^{3}$, and Richard Sever ${ }^{4}$}

\author{
${ }^{1}$ Department of Molecular and Cell Biology, University of California, Berkeley, California 94720-3202 \\ ${ }^{2}$ Molecular and Cell Biology Laboratory, Salk Institute for Biological Studies, La Jolla, California 92037 \\ ${ }^{3}$ Cancer Center, Weill Cornell Medical College, New York, New York 10065 \\ ${ }^{4}$ Cold Spring Harbor Laboratory, Cold Spring Harbor, New York 11724 \\ Correspondence: jthorner@berkeley.edu
}

\section{SUMMARY}

We have come a long way in the 55 years since Edmond Fischer and the late Edwin Krebs discovered that the activity of glycogen phosphorylase is regulated by reversible protein phosphorylation. Many of the fundamental molecular mechanisms that operate in biological signaling have since been characterized and the vast web of interconnected pathways that make up the cellular signaling network has been mapped in considerable detail. Nonetheless, it is important to consider how fast this field is still moving and the issues at the current boundaries of our understanding. One must also appreciate what experimental strategies have allowed us to attain our present level of knowledge. We summarize here some key issues (both conceptual and methodological), raise unresolved questions, discuss potential pitfalls, and highlight areas in which our understanding is still rudimentary. We hope these wide-ranging ruminations will be useful to investigators who carry studies of signal transduction forward during the rest of the 21 st century.

\section{Outline}

1 Signaling in the atomic age

2 Seeing is believing

3 Signaling in the postgenomic era

4 Modularity in signaling

5 Posttranslational modifications and signaling
6 Integration of cell metabolism and signaling

7 Signal diversity

8 Prospectus

References 
J. Thorner et al.

\section{SIGNALING IN THE ATOMIC AGE}

Our perceptions about signal transduction processes and the functions of the molecules involved have blossomed as a consequence of technological advances in genomics (Rogne and Taskén 2013), mass spectrometry (Bensimon et al. 2012), structure determination (Chiu et al. 2006), and computational power (Chakraborty and Das 2010). The increase in structural biology, in particular, has been extremely important. It is often helpful, especially for newcomers, to illustrate information flow, protein-protein interactions, and other basic concepts by using schematic diagrams. However, the acquisition of structural information about signaling molecules at atomic resolution has given us unprecedented insights into the way signaling proteins operate as nano-machines to control cellular processes. This level of detail is vital to convey to the advanced student, the practitioner at the bench, and those attempting to develop effective therapeutics. Starting more than 20 years ago with acquisition of the first three-dimensional picture of a protein kinase, cAMP-dependent protein kinase (also known as protein kinase A, PKA) (Knighton et al. 1991) and elucidation of crystal structures of the first noncatalytic folds found in many signaling proteins- $-\mathrm{SH} 2$ domains (which recognize phosphorylated tyrosine residues in various sequence contexts) (Waksman et al. 1992), and SH3 domains (which recognize PxxP motifs and variants thereof) (Musacchio et al. 1992) — the pace of advance has been truly remarkable.

Structural information at atomic resolution has, for example, turned our rather naïve initial views about how ligand-induced dimerization of receptor-tyrosine kinases leads to activation into a highly nuanced view of the articulation and dynamics of these molecules (Jura et al. 2011; Bessman and Lemmon 2012; Endres et al. 2013). The same is true for the cytosolic protein-tyrosine kinases (Bradshaw 2010; Kiu and Nicholson 2012). Similarly, deconvolution of the structures of polytopicintegral membrane proteins, in particular G-protein-coupled receptors (GPCRs), which seemed an insurmountable technological challenge less than 10 years ago, has yielded to new methodology and produced a flood of high-resolution structures for these molecules (Stenkamp et al. 2005; Granier and Kobilka 2012; Katritch et al. 2013), and even a four-protein complex of one GPCR with its cognate heterotrimeric G protein (Rasmussen et al. 2011). However, some molecules critical for signaling remain recalcitrant to this approach. For example, although structural information at atomic resolution has had an enormous impact on our level of understanding of the function and regulation of certain classes of ion channels (MacKinnon 2003), many that have critical roles in vision, taste, mechanical sensation (hearing and touch), pain perception, and other aspects of neurotransmission and neurosensation have not yet been visualized in their native full-length form (Li et al. 2011; Lau et al. 2012; Kumar and Mayer 2013). Nonetheless, arguably, the depth of our understanding of detailed molecular mechanisms at the atomic level has come farther and faster for proteins involved in signal transduction than for proteins in many other areas of biology. That pace needs to be continued.

\section{SEEING IS BELIEVING}

Technological advances in imaging also deserve special mention because of the critically important information that direct visualization provides about the localization and movement of signaling molecules in individual cells. The demonstration that a green fluorescent protein (GFP) from a jellyfish could be fused to a protein of interest and the resulting chimera used to observe the concentration and subcellular distribution of signaling molecules in live cells in real time via fluorescence microscopy was a seminal breakthrough (Chalfie et al. 1994). The discovery of GFP provoked a hunt for additional proteins capable of generating a fluorophore internally, such as DsRed (Miyawaki 2002), or by coupling to endogenous chromophores such as biliverdin (Shu et al. 2009; Piatkevich et al. 2013). Successful mutational strategies allowed modification of the spectral properties of GFP itself (Zacharias and Tsien 2006; Tsien 2009) and its relatives (Shaner et al. 2008; Piatkevich and Verkhusha 2010). Similarly, mutagenesis of small single-chain enzymes has yielded variants that self-label covalently with a fluorophore substituent in the course of one catalytic turnover when provided with an appropriate cell-permeable, dye-derivatized substrate. This approach produced the so-called SNAP (Corrêa et al. 2013), CLIP (Gautier et al. 2008), and Halo (Encell et al. 2012) tags. It is important to emphasize, however, that studies tracking hybrid proteins must be confirmed by independent approaches (e.g., genetic complementation) that show they retain biological function; sadly, such constructs are often used and conclusions drawn without this necessary validation.

There are additional tactics for bioorthogonal labeling of proteins (Debets et al. 2013; Herner et al. 2013). For example, unnatural amino acid (UAA) technology (Liu and Schultz 2010; Chin 2014) offers another route for genetically encoding a protein with a site-specific fluorescent tag. By extending the genetic code and making the necessary changes to the translation machinery, one can incorporate at any specified position in a protein a 21st amino acid (either a UAA with a fluorescent side chain [Kang et al. 2013; Niu and Guo 2013] or a UAA whose side chain can be readily coupled to a cell-permeable fluorophore [Borr- 
mann et al. 2012], or even two different UAAs at distinct sites in the same protein [Xiao et al. 2013a]). Together, all of these methods provide a researcher with a broad palette for fluorescent labeling, permitting simultaneous interrogation of the locations of and/or conformational changes in multiple signaling proteins in the same cell.

Such labels have become even more useful because of concomitant advances in fluorescence imaging that have taken us well beyond conventional epifluorescence microscopy. These include dramatic improvements to the quality of the microscopes themselves and, most notably, the advent of various optical and computational methods to determine the centroid of a point source of emitted fluorescence, such as photoactivated localization microscopy (PALM), stochastic optical reconstruction microscopy (STORM), and stimulated emission-depletion microscopy (STED) (Sengupta et al. 2012; Coelho et al. 2013). These techniques (collectively, referred to as super-resolution fluorescence microscopy) achieve a spatial resolution better than the diffraction limit of the illuminating light $(\sim 200 \mathrm{~nm})$, providing the capability to discriminate between molecules separated by only $\sim 30 \mathrm{~nm}$ (Huang et al. 2009). Spinning-disk confocal microscopy, deconvolution microscopy, and two-photon microscopy allow image reconstruction in three dimensions, providing spatial information. Depending on the nature of the molecule, the process, and the cellular region being examined, techniques such as total internal reflection fluorescence microscopy or selective plane illumination microscopy can be used to follow the movement of single molecules by illuminating only a very thin region of the cell.

Fluorescence speckle microscopy and photoactivation microscopy use photoconvertible forms of fluorescent protein tags to permit monitoring of the motion of individual molecules by limiting the number of detectable molecules in the field of view. Fluorescence recovery after photobleaching and fluorescence lifetime imaging, meanwhile, permit measurement of the dynamics of the population of fluorescently labeled molecules in the cell. Förster resonance energy transfer (FRET) between two different proteins tagged with distinct fluorescent labels with appropriate spectral overlap can be used to determine if they ever approach each other more closely than $10 \mathrm{~nm}$ (Schmid and Birbach 2007; Miyawaki 2011; Zhou et al. 2012). A related method is bimolecular fluorescence complementation, in which the amino-terminal half of a fluorescent protein is tethered to one protein, whereas the carboxy-terminal half is tethered to another; if the two proteins interact, they stabilize association of the two halves of the fluorescent reporter, allowing acquisition of its fluorescent state (Kerppola 2009; Filonov and Verkhusha 2013). Collectively, application of such methods can provide crucial information about the spatial and temporal behavior of molecules responsible for signaling. Microfluidic devices in which individual cells are restrained provide a convenient means to carefully manipulate their conditions and monitor their resulting responses by such techniques (Cheong et al. 2009).

The ability to tag a protein that undergoes a marked conformational change on ligand binding with a fluorescent protein that undergoes a concomitant spectral change, or tag a protein at each end with two compatible fluorophores that undergo a FRET change in response to ligand binding or a posttranslational modification, has permitted construction of in vivo biosensors that report responses in individual cells, such as an increase in intracellular calcium ion concentration (Akerboom et al. 2012; Tong et al. 2013 ) or activation of a particular protein kinase (Kunkel et al. 2007; Harvey et al. 2008; González-Vera 2012). Similarly, fusion of fluorescent labels to ion channels (Guerrero and Isacoff 2001; Mutoh et al. 2011) and photoinduced electron transfer to membrane-seeking chemical probes (Miller et al. 2012) provide sensitive readouts for voltage changes in individual neurons.

Conversely, fluorescently tagged ion channels whose functional properties can be switched reversibly between an active and inactive state in response to laser illumination allow nondestructive manipulation of cell behavior by light of a particular wavelength (Gorostiza and Isacoff 2008; Kramer et al. 2013). Using genetically encoded lightcontrolled proteins to monitor and manipulate the behavior of live cells in real time has been termed optogenetics (Lima and Miesenböck 2005; Miller 2006; Fenno et al. 2011). Other molecules that undergo dramatic conformational changes on light absorption have also been exploited, such as flavin adenine dinucleotide-binding light-, oxygen-, or voltage-sensing (LOV) domains (Christie et al. 2012; Renicke et al. 2013). Likewise, following pioneering work of Peter Quail (Leivar and Quail 2011) and Clark Lagarias (Rockwell et al. 2006) on how plant and cyanobacterial phytochromes recruit protein cofactors (PIFs) in a light-dependent manner to regulate transcription, the light-gated dimerization of a protein fused to an approximately 900-residue amino-terminal chromophore-containing fragment of a phytochrome and another protein fused to an approximately 100-residue fragment of a PIF has been exploited to control the initiation of signaling in animal cells (Levskaya et al. 2009; Toettcher et al. 2013). Note, however, that the necessary segment of the phytochrome can be difficult to work with because of its large size (nearly $100,000 \mathrm{kDa}$ ) and the requirement to supply exogenously its cognate linear tetrapyrrole chromophore (either phytochromobilin or phycocyanobilin), which does not readily enter all cell types. These approaches owe much to methods for small-molecule-driven protein-pro- 
J. Thorner et al.

tein association (Crabtree and Schreiber 1996; Farrar et al. 1996), for example, those using the immunosuppressant (and mTORC1 inhibitor) rapamycin. In the presence of rapamycin, a protein fused to the rapamycin-binding protein FKBP12 will interact with a protein fused to the FKBP12-rapamycin-complex-binding domain of mTOR, and both fusion proteins can also be marked with fluorescent tags.

Advances in instrumentation have also made possible the imaging of bioluminescent reporters, such as luciferase, in intact tissues and whole animals (Sadikot and Blackwell 2008; Close et al. 2011). Microscopes equipped with ultrasensitive charge-coupled device cameras optimized for the near infrared range and upright parcentered and parfocal optical configurations that provide a very long working distance and high numerical aperture make the capture of this light possible. This form of optical imaging is low cost and noninvasive and facilitates real-time in situ visualization of signaling. For example, luciferase, either intact or split, when fused to a protein(s) of interest can be used for analyzing where a protein is located or in what cells a proteinprotein interaction occurs, respectively (Stynen et al. 2012); and a luciferase gene placed downstream of another gene's promoter can serve as a transcriptional reporter to identify the cells that respond to a signal (Ravnskjaer et al. 2013).

Improvements in imaging have not been limited to light microscopy. Advances in electron microscopy (EM), including electron diffraction, cryo-EM, electron tomography, and single-particle reconstruction, allow visualization of the arrangement of the constituent polypeptides in large multiprotein complexes (Baumeister and Steven 2000; Frank 2009; Lander et al. 2012). Development of enzymic probes compatible with EM fixation and sectioning methods, such as miniSOG (Shu et al. 2011) and APEX (Martell et al. 2012), provide means to determine where a given signaling protein is localized at the ultrastructural level. An additional advantage of miniSOG is that this flavoprotein can also be visualized by light microscopy in living cells, which can then be processed at any given time during a signaling process for subsequent analysis at the EM level (Butko et al. 2012).

Our ability to obtain a snapshot of what is happening to individual proteins in single cells in response to an external cue is not confined to microscopy. Recently developed mass spectrometry methods allow protein constituents in a single cell to be quantified, using heavy-atom-labeled antibodies against those proteins and/or specific phospho-sites on those proteins. This method has been dubbed "mass cytometry" because fluorophore-tagged antibody reporters are replaced with isotopically tagged ones, and depends on the use of an inductively coupled-plasma time-of-flight mass spectrometer, which can resolve up to 100 different rare-earth-metal-labeled antibody probes with single-cell sensitivity (Bandura et al. 2009; Zivanovic et al. 2013). This technology has been used successfully to define the state of 31 different proteins in particular cell types of the hematopoietic lineage in bone marrow (Bendall et al. 2011), examine the effect of 27 small-molecule protein kinase inhibitors on 14 different phosphorylation sites in human peripheral blood mononuclear cells from eight donors (Bodenmiller et al. 2012), and identify T cells specific for particular epitopes among 77 candidate rotaviral antigens (Newell et al. 2013). However, the sophisticated instrumentation necessary is expensive and not widely available. Moreover, the cells being analyzed are fixed, "stained" with the antibodies, and then destroyed in the process. Thus, cells assigned to a given signaling state by their mass cytometry signature cannot be recovered and followed subsequently (unlike in conventional cytometry, in which the cells can remain viable and be separated on the basis of their fluorescence signature by a fluorescenceactivated cell sorter).

Additional technological leaps make feasible observation of single signaling molecules in action in vitro. Standard biochemical measurements yield an ensemble average and, even for a purified preparation, it is frequently difficult to discern what fraction of the molecules present are properly folded and functional. In contrast, the use of optical traps ("molecular tweezers") allows measurement of the biophysical properties of an individual protein in operation (Greenleaf et al. 2007; Moffitt et al. 2008). Similarly, in silico molecular dynamic simulations based on crystal structure coordinates and/or nuclear magnetic resonance constraints now allow us to predict the accessible conformational states of a signaling protein (Baker 2006; Friedland and Kortemme 2010), or how it might dock with another protein or small molecule (Kolb et al. 2009). This approach has been made accessible by construction of computers with the necessary speed and capacity (Dror et al. 2012) (and/or linking many computers together via the Internet) (Beauchamp et al. 2012) and corresponding improvements in algorithms for calculating the necessary energetics (Brooks et al. 2009; Lane et al. 2013).

\section{SIGNALING IN THE POSTGENOMIC ERA}

Genetic methods have been just as important for the progress made in deciphering signal transduction pathways. These biological regulatory mechanisms have roots deep in evolutionary time. Thus, genetic studies in single-celled eukaryotic microbes (e.g., budding [Thorner 2006] and fission [Otsubo and Yamamato 2008] yeast) and experimentally tractable invertebrates (e.g., fruit flies [Thompson 2010] and nematodes [Bargmann and Kaplan 1998]), as 
well as in model vertebrates (including zebrafish [Moro et al. 2013] and the mouse [Nardella et al. 2010; Guerra and Barbacid 2013]), have been invaluable. Genetic analysis of these organisms has supplied critical information about gene products that represent, generate, and/or propagate signals that control cell metabolism, growth, size, division, differentiation, shape, and motility, and that, when defective, cause disease. The development of instrumentation for facile DNA sequence determination (Shendure et al. 2004; Ståhl and Lundeberg 2012) and effective algorithms for comparative genomics (Venter et al. 2003; Dewey and Pachter 2006; Jiang et al. 2009; Washietl et al. 2012) have permitted rapid decoding of entire genomes. With this comprehensive information, the genetic findings made in model organisms can illuminate related processes in all other living things, including humans, because of the high degree of evolutionary conservation in major signaling pathways. Moreover, interrogating the entire biosphere will continue to be as important for understanding human biology and disease as studies of human beings themselves. This viewpoint is readily defensible especially when one considers that many clinically useful drugs that modulate signaling are natural products. For example, rapamycin was discovered only because someone chose to isolate a new aerobic Gram-positive filamentous bacterium (Streptomyces hygroscopicus) from the soil of Easter Island (Rapa Nui in Polynesian) (Vézina et al. 1975).

With the rise in genetics and genomics, sophisticated new tools for genome engineering are allowing analysis of the function of genes in human cells, including those involved in signaling, by many of the paradigmatic methods initially developed for use in studies of model organisms. These methods exploit nucleases and DNA- and RNAbinding proteins derived from yet other microorganisms (Urnov et al. 2010; Carroll 2011; Gaj et al. 2013; Wei et al. 2013). At the same time, computational methods for identifying conserved structural domains and other sequence motifs in proteins have also advanced greatly (Doolittle 1995; Copley et al. 2002; Galperin and Koonin 2012; Huang et al. 2013).

\section{MODULARITY IN SIGNALING}

One revelation derived from the explosion of sequence and structural information is the extent to which signaling proteins appear to have arisen during evolution by the shuffling and assembly of readily identifiable modules. These stably folded domains, joined by flexible linkers, frequently serve as recognition elements that mediate specific protein-protein interactions that link them together in specific complexes. Understanding the dynamics of the assembly of such complexes, how they direct signal propa- gation, enhance signaling efficiency, and insulate pathways against inadvertent stimulation continues to be an area of ongoing research.

Another important consequence of the modular nature of the proteins involved in cellular regulation is that such an architecture allows the constituent domains to evolve discrete and separable functions, which we are just beginning to uncover and appreciate. For example, the p $110 \beta$ isoform of the catalytic subunit of Class 1A phosphoinositide 3-kinase (PI3K) can generate phosphatidylinositol 3,4,5-trisphosphate $\left(\mathrm{PIP}_{3}\right)$ at the plasma membrane via its carboxy-terminal kinase domain in response to growthfactor-initiated signaling by receptor-tyrosine kinases or GPCR activation (Vadas et al. 2011; Dbouk et al. 2012; see also Hemmings and Restuccia 2012). However, on growth factor withdrawal, $\mathrm{p} 110 \beta$ dissociates from receptors, interacts via its so-called helical domain with the small GTPase Rab5 and helps stabilize the GTP bound state of Rab5 (Dou et al. 2013). This interaction stimulates autophagy because increasing the amount of Rab5-GTP that decorates internal membranes results in recruitment of the class III PI3K hVps34, which generates the phosphatidylinositol 3-phosphate necessary for assembly of preautophagosomes (Parzych and Klionsky 2014). The mitogenactivated protein kinase (MAPK) kinase MEK1 provides another example. It was thought to be simply a dedicated component of the Ras-Raf-MEK-ERK signaling cascade (English and Cobb 2002; Roskoski 2012; see also Morrison 2012); however, we now know that once feedback phosphorylated on its amino-terminal extension by the kinase ERK, MEK1 forms a ternary complex with a multidomain adaptor protein called MAGI-1, which is necessary for membrane recruitment of the $\mathrm{PIP}_{3}$-specific phosphatase PTEN; MEK1 thereby promotes down-regulation of the $\mathrm{PIP}_{3}$-dependent protein kinase Akt (Zmajkovicova et al. 2013). A related issue is that inherently disordered regions in some proteins adopt alternative structures when associated with different interaction partners, leading to different outcomes. The $\mathrm{p} 53$ transcription factor provides a particularly dramatic example of this (Dunker et al. 2008; Joerger and Fersht 2008; Freed-Pastor and Prives 2012).

The phenomenon whereby a protein has multiple distinct functions has been dubbed "moonlighting" (Jeffery 2009). The potential for this evolving is greatest in multidomain proteins, but not restricted to them. For example, one of the splice variants of the muscle form of the glycolytic enzyme pyruvate kinase, PKM2 (Hitosugi et al. 2009), appears to have other roles. On the one hand, PKM2, when proline-hydroxylated by prolyl hydroxylase 3 , seems to associate with the transcription factor HIF1 $\alpha$ and act as a coactivator that promotes expression of HIF $1 \alpha$-dependent genes (Luo et al. 2011). On the other hand, once tyrosine 
phosphorylated in response to growth factors, PKM2 may undergo a switch in both oligomerization state (from a tetramer to a dimer) and catalytic function (from its glycolytic role to a protein kinase), and affect transcription by phosphorylating both histones (e.g., T11 on histone H3, which promotes acetylation at $\mathrm{K} 9$, a modification that stimulates transcription) (Yang et al. 2012) and transcription factors (e.g., Y705 in STAT3, which promotes its dimerization and transactivator function) (Gao et al. 2012).

Such instances of moonlighting in signaling proteins may help explain how the intricacies of human biology are achieved with only 21,000 or so protein-coding genes ( just four times as many as a yeast cell). Thus, investigators need to be alert to the possibility that moonlighting could contribute in unanticipated ways to the biological complexity observed in a signaling process, above and beyond alternative pre-mRNA splicing, differential protein processing, and other mechanisms for generating protein diversity that we already understand.

\section{POSTTRANSLATIONAL MODIFICATIONS AND SIGNALING}

For many of the stably folded domains that mediate specific protein-protein interactions in signal transduction (see Lee and Yaffe 2014), target recognition depends on a posttranslational modification of an amino acid side chain, from phosphorylation to methylation, acetylation, and ubiquitylation (Pawson and Nash 2003; Bhattacharyya et al. 2006; Nash 2012; Sadowski and Taylor 2013). Indeed, proteins can be covalently modified to form all sorts of other adducts and more than 300 types are known (Krishna and Wold 1993; Sims and Reinberg 2008; Farley and Link 2009; Hart et al. 2011; Scarpa et al. 2013). The proteinprotein interactions dependent on such modifications are generally dynamic because these groups are installed and removed by enzymes whose own activity often depends on signaling - in particular, protein phosphorylation (Hunter 2012; Jin and Pawson 2012) — which makes the study of protein kinases and phosphoprotein phosphatases central to our understanding of signal transduction (Cohen 2002; Fischer 2013). This area of research has driven development of new tools for globally interrogating both the kinome (Knight et al. 2013) and the phosphoproteome (Leitner et al. 2011), including position-oriented, combinatorial, synthetic peptide libraries (Turk et al. 2006; Arsenault et al. 2011) and immobilized whole proteome arrays ("protein chips") (Ptacek and Snyder 2006) for delineating kinase-substrate specificity, ever more specific small-molecule kinase inhibitors (Cohen and Alessi 2013), genetic approaches to uniquely sensitize a given kinase to inhibition (Elphick et al. 2007; Knight and Shokat 2007; Feldman and Shokat 2010; Kliegman et al. 2013), selective chemical tags to covalently label particular kinases and phosphatases or their substrates (Allen et al. 2007; Patricelli et al. 2007; Hertz et al. 2010; Sadowsky et al. 2011; Miller et al. 2013), yeast two-hybrid screens (Cook et al. 1996; Fukada and Noda 2007; Sopko and Andrews 2008), and other strategies to trap particular kinases and phosphatases in complexes with their targets (Blanchetot et al. 2005; Boubekeur et al. 2011), as well as sophisticated mass spectrometry instrumentation and corresponding methods for detecting and cataloging phosphoproteins (Cohen and Knebel 2006; Chi et al. 2007; Gevaert and Vandekerckhove 2009; Palumbo et al. 2011; Engholm-Keller and Larsen 2013; Loroch et al. 2013; Roux and Thibault 2013).

In signaling that regulates cell growth and division (Rhind and Russell 2012; Duronio and Xiong 2013), the actions of protein kinases are pivotal (Morgan 2007). The chemical constraints on how these enzymes operate have underappreciated implications for pathway logic and dynamics. Every catalytic turnover of a protein kinase requires that the phosphoacceptor sequence and ADP dissociate from the jaws of the active site to permit entry of a fresh molecule of ATP into the back of the catalytic pocket for the next phosphotransfer event (Tarrant and Cole 2009; Lassila et al. 2011). How then can the multifarious protein kinases present in a cell at any given time avoid adventitious modification of inappropriate targets? Likewise, how can a protein kinase phosphorylate a given substrate processively at several sites, as is often the case?

Part of the answer may lie in condition-, developmentalstage-, and tissue-specific expression of the genes encoding these protein kinases and their corresponding substrates, which could ensure that they are available only in the right cells under the right circumstances. RNA-seq experiments (for this method, see McGettigan 2013) and studies using beads containing a mixture of protein-kinase-binding inhibitors followed by identification of the bound enzymes by mass spectrometry show, however, that at least certain immortalized cell lines and some breast tumor tissue express the majority $(60 \%-75 \%)$ of the kinome repertoire (Duncan et al. 2012). But, kinase targets may be more cell-type specific. For example, arachidonic acid, the precursor for eisocanoids, is released from membrane phospholipids in tissues such as spleen, gut, white fat, and macrophages by the action of the known kinase target cytosolic phospholipase A2 (cPLA2). In humans, this enzyme exists as six isoforms (cPLA2 $\alpha$, CPLA2 $\beta$, CPLA2 $\gamma, \operatorname{cPLA} 2 \delta, \operatorname{cPLA} 2 \varepsilon$, and cPLA2 $\zeta$ ) encoded by distinct genes. The most ubiquitously expressed and well-studied isoform, cPLA2 $\alpha$, is phosphorylated at multiple sites by various different protein kinases. Depending on the cell type and agonist examined, phosphorylation seems to regulate both membrane binding and 
catalytic activity of cPLA2 $\alpha$ (Ghosh et al. 2006; Dennis et al. 2011). The biochemical properties and tissue distributions of the other five isoforms suggest that regulation of their phosphorylation is distinct from that of CPLA2 $\alpha$ and may also involve other mechanisms. Moreover, although cPLA2 is responsible for arachidonate generation in many tissues, this fatty acid is supplied in brain, liver, and lung via the action of a separate class of serine acylhydrolase, MAGL, which further extends the regulatory possibilities (Savinainen et al. 2012; Mulvihill and Nomura 2013).

There are many other mechanisms that can dictate how a protein kinase achieves its target specificity (see Lee and Yaffe 2014). On the one hand, various molecular matchmaker strategies (see below) have evolved to ensure that a protein kinase encounters its proper substrates with high probability and efficiency (Endicott et al. 2012). On the other hand, for subsequent events to unfold, the rate of phosphorylation must exceed the rate of dephosphorylation by ever-present and more promiscuous phosphoprotein phosphatases (Cohen 1992). For example, because of just this sort of antagonism, during the response to stimulation by epidermal growth factor (EGF), the phosphorylated tyrosine sites on the cytosolic domain of the EGF receptor turn over 100-1000 times before maximal receptor phosphorylation is achieved (Kleiman et al. 2011). Thus, any elevation in phosphorylation detected in response to a stimulus is not simply caused by modifications that are installed and remain until the signal is terminated. Hence, the hydrolytic activity of phosphatases ensures that inefficient or inadvertent phosphorylation events have no physiological consequence.

Protein kinases that act on targets at a cellular membrane are either integral membrane proteins (e.g., receptor tyrosine kinases) or possess domains that permit association with receptors or receptor-associated proteins (e.g., the JAK family of protein tyrosine kinases bound to the cytosolic segments of cytokine receptors) and/or are posttranslationally modified with substituents (e.g., $\mathrm{N}$ myristoyl and $S$-palmitoyl groups) that strongly promote partition into the membrane (e.g., the Src family of protein tyrosine kinases) (Groves and Kuriyan 2010). In other instances, association of the kinase and its substrate with a third partner (a scaffold, linker, or anchor protein) brings about the necessary propinquity and, in addition, enhances reaction rate by achieving a high local concentration of the reactants (Ferrell 2000; Kuriyan and Eisenberg 2007). Thus, if biochemical analysis of the proteins associated with a given protein kinase, or genetic analysis of a process, reveals another gene in which mutation yields a phenotype similar to that resulting from loss of the kinase, and the gene product in question has no obvious catalytic function itself, then it may serve such a scaffolding role. Moreover, there is emerging evidence that at least one mammalian protein involved in the innate immune response to RNA virus infection serves as just such a signal-activating platform when, in prion-like fashion, it is converted into an amyloid-like fibril (Hou et al. 2011; Wu 2013).

In some cases, phosphorylation of a substrate by one protein kinase converts a sequence motif into a high-affinity binding site for, and permits its subsequent phosphorylation by, another protein kinase. The first of such two-step modifications is termed "priming." For example, the prior phosphorylation of substrates by the cell cycle kinase cyclindependent kinase (CDK) 1 can generate a phospho-epitope recognized by the Polo box domains of the Polo family of protein kinases, which execute later cell cycle events (Lowery et al. 2005; Strebhardt 2010). This feature can be exploited in other ways. For example, a peptide library approach (Turk and Cantley 2003) indicates GSK3 $\beta$ is a protein kinase that strongly prefers to phosphorylate a primed substrate, one that possesses a serine or threonine residue in a sequence with a phosphorylated serine residue at position +4 . When S9 in GSK3 $\beta$ is phosphorylated by Akt, however, this modification creates a substrate-like sequence that moors its own amino terminus in its active site, thereby blocking GSK3 $\beta$ action on other primed substrates (Frame and Cohen 2001; Weston and Davis 2001). For both kinetic and thermodynamic reasons, intramolecular interactions are favored over intermolecular associations. Hence, investigators should always be aware that phosphorylation sites present in a kinase may serve such roles.

In many cases, a protein kinase recognizes and interacts with its substrate via at least one other association distinct and physically distant from the active-site-phosphoacceptor-sequence interaction. Such secondary points of enzyme-substrate binding are termed docking sites (Bardwell and Thorner 1996; Reményi et al. 2006; Goldsmith et al. 2007). The more docking interactions between a kinase and its target, the higher the probability that the substrate will not dissociate from the enzyme in the time it takes for the next catalytic turnover event. Thus, multiple docking interactions ensure that the enzyme will stay bound to the same substrate molecule (and phosphorylate another phosphoacceptor site, if there is one) rather than jump to a new substrate. Moreover, such docking interactions supply additional binding energy that makes it possible for substrate phosphorylation to occur at noncanonical (suboptimal, lower affinity) phosphorylation sites. Such considerations help explain why an investigator may find, perhaps perplexingly, nonconsensus sites in mass spectrometry data, even when they are using a purified substrate and protein kinase.

A particularly illustrative example of the vital role of such docking interactions in ensuring processive multisite 
phosphorylation that is now well understood at the mechanistic level is CDK1-dependent phosphorylation of the yeast CDK inhibitor Sic1 (Nash et al. 2001). In the case of Sic1, the phosphomodifications are a prelude to its timely ubiquitylation by an SCF-type ubiquitin ligase (Silverman et al. 2012) whose substrate recognition subunit (Cdc4) interacts with phosphoepitopes (Tang et al. 2012). In Sicl, there is a sequence motif (VLLPP) that binds with high affinity to a site in the $G_{1}$ cyclin $(C \ln 2)$ in Cln2-CDK1-Cks1 complexes; similarly, there are four interspersed RxL motifs that bind to a site in the $\mathrm{S}$ phase cyclin (Clb5) in Clb5-CDK1-Cks1 complexes. The obligatory Cks1 subunit in both CDK complexes contains a pocket that preferentially binds phospho-TP sites (CDKs are generally highly selective for -SP- and -TP- sites); hence, once phosphorylated at any such site, the phosphoepitope-Cks1 interaction provides yet another docking interaction. After a sufficient amount of the Cln2-bound CDK1Cks1 complex builds up during $\mathrm{G}_{1}$ phase, it holds onto Sic1 via two contacts (active-site-phosphoacceptor-site binding and VLLPP-motif-Cln2-docking-pocket association); following the first phosphorylation, there are now three such interactions possible (active-site-phosphoacceptorsite binding, VLLPP-motif-Cln2-docking-pocket association, and phosphoepitope-Cks1 interaction), which explains initiation and establishment of processive phosphorylation (Kõivomägi et al. 2011). Similarly, as the amount of Clb5-bound CDK1-Cks1 builds up in late$\mathrm{G}_{1}$ /early-S phase, maintenance and completion of processive multisite phosphorylation by the Clb5-CDK1-Cks1 enzyme is very efficient, given that it has four times the probability of engaging an RxL motif than the $\mathrm{Cln} 2$ CDK1-Cks1 complex does a single VLLPP motif (Venta et al. 2012).

\section{INTEGRATION OF CELL METABOLISM AND SIGNALING}

Intermediates in metabolism may have been the first intracellular (and intercellular) signaling molecules, acting as feedback or feed-forward regulators (either allosteric effectors or covalent modifiers) of enzymes in metabolic pathways and transcription factors that controlled expression of those enzymes. Our focus on other levels of regulation has perhaps diverted us from exploring these more ancestral control mechanisms because, in metazoans, GPCR and protein kinase signaling in response to hormones and growth factors override the selfish metabolic needs of any given cell, in favor of the needs of the organism (see Hardie 2012).

So, just as proteins can have moonlighting functions, we need to better understand the manifold functions in signaling of what were formerly considered merely metabolic intermediates. For example, until the stimulatory function of histone lysine $\varepsilon$ - $N$-acetylation in chromatin remodeling and gene expression was uncovered (Racey and Byvoet 1971; Turner 1991), acetyl-CoA was presumed to have only the less glamorous role of conveying carbon from glycolytically generated pyruvate, or the breakdown of fatty acids, to the tricarboxylic acid (TCA) cycle for energy generation in the mitochondrion. We now know that acetyl-CoA has other roles that impinge critically on the capacity of a cell to signal (Lin et al. 2013). For example, in neurons and some other cells, it is needed for synthesis of the central neurotransmitter acetylcholine. Moreover, in all cells, three molecules of acetyl-CoA can condense to form HMG-CoA for the mevalonate pathway to make both isoprenoid compounds (including the farnesyl and geranylgeranyl moieties attached to the carboxy-terminal CAAX motifs in many small GTPases involved in signaling, such as H-Ras and K-Ras) (Berndt et al. 2011; Resh 2012) and cholesterol (which is not only important for the architecture and fluidity of the membrane in which receptors reside, but is also attached to the carboxyl terminus of an important developmental signaling protein, Hedgehog; Creanga et al. 2012; Ingham 2012). Yet another role for acetyl-CoA that affects signaling has recently turned up. The $\alpha-N$-acetylation of Met1 in the Rub1/Nedd8-specific E2 enzyme Ubc12 (although an irreversible modification, once installed) increases the avidity of its binding to a hydrophobic pocket in its cognate E3 ligase Dcn1 and thereby stimulates Nedd8-ylation of the Cul1 scaffold protein (Monda et al. 2013), which is necessary, in turn, for assembly and activity of the SCF-type E3 ligases that control the ubiquitin-dependent degradation of numerous signaling proteins (Deshaies et al. 2010). It is worth noting that, simply through substrate availability (and dependent on the relative $K_{m}$ values of the various $\varepsilon$ - $N$-lysine acetyltransferases), the level of acetyl-CoA will dictate the rate of acetylation of histones and other proteins with concomitant consequences for gene expression and other cellular functions (Starai et al. 2004; Londoño Gentile et al. 2013; Zhang et al. 2013).

Acetyl-CoA is just one prominent nexus linking cell metabolism and signaling. The levels of other key metabolites have multiple effects that influence both metabolism and cell signaling in ways that we are just beginning to understand. For example, 2-oxoglutarate (2OG, also known as $\alpha$-ketoglutarate) is a central intermediate in the TCA cycle, but also needed for amino acid interconversion and breakdown by transamination, which may affect the activity level of a major amino acid sensor and growth regulator, mTORC1 (Bar-Peled et al. 2012). In addition, 2OG is a critical cofactor for the Jumonji class of 
histone methyl-N-lysine demethylases (Hou and Yu 2010), TET family 5-methylcytosine hydroxylases ( Wu and Zhang 2011), and EglN-type prolyl-4-hydroxylases (Freeman et al. 2003), all of which likely affect the level of expression of genes encoding signaling proteins. Moreover, neomorphic mutations in isocitrate dehydrogenase (both IDH1 and IDH2) that prevent oxidative decarboxylation of isocitrate to $2 \mathrm{OG}$, but catalyze instead NADPH-dependent reduction of 2OG to (R)-2-hydroxyglutarate (Dang et al. 2009), an antagonist of 2OG-dependent protein and DNA demethylation, are strongly associated with certain cancers, clearly implicating altered metabolism in tumorigenesis (Losman and Kaelin 2013).

Unsurprisingly, the major cellular methyl donor, $S$ adenosylmethionine (AdoMet), is important not only for methylation of DNA bases and epigenetic silencing (Guibert and Weber 2013), but also for protein methylation that influences signaling. For example, AdoMet-dependent $N$ methylation of an arginine residue in the inhibitory factor Smad6 dissociates it from activated bone morphogenetic protein (BMP) receptors, alleviating inhibition and enabling the type I subunit of the BMP receptor complex to phosphorylate the transcription factors Smad1 and Smad5, which permits their nuclear import and activates their gene regulatory function (Xu et al. 2013). Similarly, succinylCoA is another central intermediate in the TCA cycle, and lysine succinylation and cysteine succination have both been recently identified as posttranslational modifications of proteins that influence the properties of the enzymes to which they are attached (Zhang et al. 2011; Lin et al. 2012). An open-ended question for future study is how many other cellular metabolites lie at the crossroads between central metabolism and cell signaling or are involved in the fine-tuning of biological processes that impinge on signaling.

\section{SIGNAL DIVERSITY}

During evolution, mechanisms have arisen that allow diverse cell types to sense and respond to various stimuli. In vision, light photons are absorbed by the rhodopsins (chromophore-containing GPCRs) and converted into intracellular chemical and then electrochemical changes in the rod and cone cells in the retinas of our eyes. Hearing depends on conversion of sound waves into intracellular signals via the opening and closing of stretch-activated ion channels that are mechanically coupled to ciliary bundles in specialized hair cells in our ears. In a similar way, touch depends on conversion of mechanical pressure or thermal differences into conformational changes in ion channels that open to elevate the level of intracellular calcium ions in specialized nerve fibers in our skin. Of course, other stimuli to which our senses respond are chemical in nature. Taste depends on conversion of the binding of various soluble compounds into intracellular changes in the gustatory-receptor-containing cells in the papillae on our tongues. Smell depends on conversion of the binding of various volatile compounds into intracellular signals in the olfactory-receptor-containing cells on the roof of our nasal cavity. Skin irritation caused by the common nettle in our gardens has a similar source; its trichomes inject chemicals normally made in animal cells, such as the neurotransmitter serotonin and the immune mediator histamine, thus aggravating our nerves and provoking inflammation.

Indeed, the variety of chemical signals generated by cells and to which they are able to respond is rather staggering. Many of the classical endocrine and pituitary hormones were discovered and chemically identified in the 1800 s and early 1900s. For example, Frederick Banting announced the isolation of insulin in 1921 and Fred Sanger determined its structure in 1953 (Nobel Prizes being awarded for both accomplishments). However, new types of hormones that impact cell and organismal physiology and development are still being discovered at a surprising rate, which requires that their cognate receptors and downstream mediators be identified. For example, adipose-derived leptin and its receptor (Isse et al. 1995; Tartaglia et al. 1995), neuropeptides orexin-A/hypocretin-1 and andorexin-B/hypocretin-2 and their receptors (de Lecea et al. 1998; Sakurai et al. 1998), and stomach-derived ghrelin and its receptor (Howard et al. 1996; Kojima et al. 1999), which have such critical roles in controlling the interrelated processes of energy metabolism and obesity, wakefulness and appetite, and hunger and growth, were not characterized until the late 1990s. Indeed, there are still many GPCRs and nuclear receptors that are "orphans," in the sense that their physiological ligands have not yet been determined (Civelli 2012; Pearen and Muscat 2012).

The constellation of known signaling molecules continues to expand in new and unanticipated directions. For example, it has recently been appreciated that different bacterial species, some of which are intracellular pathogens, synthesize unusual cyclic dinucleotides that control their own transcription, including cyclic-di-AMP, cyclic-diGMP, and the mixed cyclic-GMP-AMP, in all cases linked $3^{\prime}-5^{\prime}$ (Kalia et al. 2013). The presence of such compounds in mammalian cells is sensed by their binding to an endoplasmic reticulum (ER)-localized protein called STING (Woodward et al. 2010). Once activated, STING stimulates a protein kinase (TANK-binding kinase 1), which, in turn, phosphorylates and activates a transcription factor, IRF3, that regulates interferon production (Chin et al. 2013). However, STING is activated much more potently and elic- 
its a more efficacious interferon response when foreign DNA enters cells. The difference is due to the fact that cytosolic DNA binds to the regulatory domain of a mammalian enzyme, cGAMP synthase (cGAS), thereby stimulating production of cyclic-GMP-AMP in which the

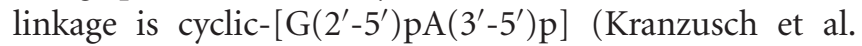
2013; Shaw and Liu 2014). This endogenously generated signal potently activates diverse hSTING variants, whereas not all of them respond well to bacterial cyclic- $\left[\mathrm{G}\left(3^{\prime}\right.\right.$ $\left.5^{\prime}\right) \mathrm{pA}\left(3^{\prime}-5^{\prime}\right) \mathrm{p}$ ] (Diner et al. 2013). Thus, mammalian cells have evolved a mechanism to generate a novel signal that permits the innate immune system to distinguish infiltration by a naked DNA from entry of a bacterial invader. Such interkingdom signaling, mediating interplay between viruses, bacteria, and mammalian cells (Lim et al. 2009; Marks et al. 2013; Pluznick et al. 2013), is clearly prevalent, has important consequences for human health, and warrants continued exploration (see also Alto and Orth 2012).

How a signal is deployed or displayed can also have information content that needs to be considered. Extracellular signaling ligands not only are released from cells via the classical secretory pathway in an autocrine, juxtacrine, or endocrine manner, but can also pass "through" cells via the process of paracytophagy and the generation of socalled argosomes (Greco et al. 2001). Such mechanisms are also used for the entry and cell-to-cell passage of many prokaryotic intracellular pathogens (Portnoy 2012). Some mammalian cell types can even engulf an entire other cell by a macroendocytic process dubbed entosis (Overholtzer et al. 2007; Florey and Overholtzer 2012). We now appreciate that cells can also generate "exosomes" (small $\sim 100$-nm-diameter vesicles) as a means for quantal export of ligands and other classes of informational molecules, including miRNAs, because, once released into extracellular fluids, they can be taken up by other cells (Bang and Thum 2012; Briscoe and Thérond 2013; Choi et al. 2013).

Cells know their place, at least in part, by making contacts with adjacent cells and components of the extracellular matrix. However, many cells types erect a single specialized projection, the primary cilium (Garcia-Gonzalo and Reiter 2012; Nozawa et al. 2013), which constrains to this one location certain classes of signaling receptors (such as the receptors for the Hedgehog family of ligands) (Wong and Reiter 2008; Perrimon et al. 2012), presumably to confer the capacity to respond only to a highly polarized or localized signal source. In contrast, other cells extend ultrafine processes and specialized filopodial extensions (also referred to as cytonemes) that can mediate cell-to-cell contacts and long-range transport of signal molecules over a distance of many cell lengths (Roy et al. 2011; Sanders et al.
2013). Similarly, juxtaposed cells in many epithelial layers are connected by gap junctions that act as portholes through which certain intracellular signals, such as an increase in cytosolic calcium ion concentration, can be spread from cell to cell (Goodenough and Paul 2009). Clearly, we still have much to learn about the interplay between signaling molecules and all levels of cellular organization.

\section{PROSPECTUS}

For the foreseeable future, signal transduction research remains a field confronted with a still vast frontier. As the contents of this collection and issues raised here make clear, unraveling signal transduction processes is a multidisciplinary enterprise. Ultimately, understanding signaling will require an appreciation for, understanding of, and the means to usefully grasp the seamless interconnectedness among all the bits of information gleaned by what were formerly considered disparate branches of the biological, chemical, and physical sciences. Fortunately, as we highlight in this collection, there are recurrent themes, general mechanisms, common strategies, and ubiquitous reactions in cell signaling that allow the complexity to be parsed out productively. Indeed, we can already discern general design principles that are allowing us to reengineer cellular responses to stimuli different from those evolved in nature (Pryciak 2009; Burrill et al. 2011; Blount et al. 2012; Lim et al. 2013).

Nonetheless, many unexpected discoveries that provide novel insights and fresh paradigms will continue to be made, and these will open up new avenues for understanding cell signaling. Some recent examples highlight this point. Remarkably, proteins of the previously uncharacterized Fam20C family turn out to be secreted atypical protein kinases that phosphorylate casein and other extracellular substrates that have important physiological roles in bone mineralization (Tagliabracci et al. 2013; Xiao et al. 2013b). This discovery raises interesting questions about how these enzymes acquire ATP in the lumen of the Golgi and whether such enzymes are made and have important roles in the nervous system, in which ATP is stored in synaptic vesicles (Zimmermann 2008) and released extracellularly to stimulate purinergic receptors (Khakh and North 2012). Likewise, it has been appreciated for decades that blood platelets also store ATP and other compounds in storage vesicles that are released extracellularly when platelets are activated at a site of injury (Da Prada et al. 1971; Higashii et al. 1985). Does this released ATP also act, in part, through Fam20C-like extracellular protein kinases? Another example is that very high serum levels of highmolecular-weight hyaluronan dramatically protect the naked mole rat against cancer (Tian et al. 2013). Hyalu- 
ronan is an extracellular proteoglycan and can bind to various cell surface receptors. How does it suppress malignant growth and/or enhance immune surveillance of precancerous tissue? And, do the same mechanisms operate in humans?

It is also clear that we have just began to scratch the surface of how microRNAs (Martinez and Gregory 2010; Mendell and Olson 2012) and other RNAs encoded in our genomes (Hancks and Kazazian 2012; Batista and Chang 2013) coordinately influence the levels of gene products involved in signaling and are themselves controlled by signaling processes. Likewise, an area of traditional biochemistry that clearly intersects with signaling in many ways is the function of various classes of proteases; yet, we understand the roles of many of these enzymes only very superficially and know even less about their physiologically relevant enzyme-substrate relationships. For example, in 2012, a new, circulating, exercise-induced regulatory hormone, dubbed irisin, was described that converts white fat into more thermogenic beige fat (Boström et al. 2012). However, irisin is identical to the ectodomain of a small (212-residue) cell surface protein, fibronectin type III domain-containing protein 5 (FNDC5), which is anchored in the plasma membrane by a single carboxyterminal hydrophobic transmembrane segment. In fact, protease-mediated shedding of the extracellular domains of transmembrane signaling proteins as separate entities with distinct functions is a common phenomenon (Horiuchi 2013). Exercise stimulates FNDC5 expression in skeletal muscle and the cleavage and release of its uniquely structured amino-terminal fibronectin-III-like ectodomain as irisin (Erickson 2013; Schumacher et al. 2013); however, the protease responsible for this shedding, and whether it too is under any sort of regulation, is unknown.

Thus, if we take the long view, studies of signal transduction are still in exponential phase with many important discoveries to come. Moreover, we anticipate continued development of evermore sophisticated experimental tools-from improvements in automated deep sequencing to characterize the global transcriptome (Malone and Oliver 2011), to new mass spectrometry instrumentation to catalog the cellular metabolome (Rubakhin et al. 2013), to further refinement of mathematical, statistical, and computational theories and methods to assist with display, interpretation, and modeling of the complex networks of relationships involved in intra- and intercellular signaling (Janes and Lauffenburger 2013; see also Azeloglu and Iyengar 2014). Continued advances of this sort will allow us to address questions at an ever greater level of detail and resolution, providing answers at the molecular level to longstanding mechanistic questions about the myriad processes that comprise cell signaling.

\section{REFERENCES}

* Reference is also in this collection.

Akerboom J, Chen TW, Wardill TJ, Tian L, Marvin JS, Mutlu S, Calderón NC, Esposti F, Borghuis BG, Sun XR, et al. 2012. Optimization of a GCaMP calcium indicator for neural activity imaging. J Neurosci 32: 13819-13840.

Allen JJ, Li M, Brinkworth CS, Paulson JL, Wang D, Hübner A, Chou WH, Davis RJ, Burlingame AL, Messing RO, et al. 2007. A semi-synthetic epitope for kinase substrates. Nat Methods 4: 511-516.

* Alto NM, Orth K. 2012. Subversion of cell signaling by pathogens. Cold Spring Harb Perspect Biol 4: a006114.

Arsenault R, Griebel P, Napper S. 2011. Peptide arrays for kinome analysis: New opportunities and remaining challenges. Proteomics 11: 4595-4609.

* Azeloglu EU, Iyengar R. 2014. Signaling networks: Information flow, computation, and decision making. Cold Spring Harb Perspect Biol doi: $10.1101 /$ cshperspect.a005934.

Baker D. 2006. Prediction and design of macromolecular structures and interactions. Philos Trans R Soc Lond B Biol Sci 361: 459-463.

Bandura DR, Baranov VI, Ornatsky OI, Antonov A, Kinach R, Lou X, Pavlov S, Vorobiev S, Dick JE, Tanner SD. 2009. Mass cytometry: Technique for real time single cell multitarget immunoassay based on inductively coupled plasma time-of-flight mass spectrometry. Anal Chem 81: 6813-6822.

Bang C, Thum T. 2012. Exosomes: New players in cell-cell communication. Int J Biochem Cell Biol 44: 2060-2064.

Bardwell L, Thorner J. 1996. A conserved motif at the amino termini of MEKs might mediate high-affinity interaction with the cognate MAPKs. Trends Biochem Sci 21: 373-374.

Bargmann CI, Kaplan JM. 1998. Signal transduction in the Caenorhabditis elegans nervous system. Annu Rev Neurosci 21: 279-308.

Bar-Peled L, Schweitzer LD, Zoncu R, Sabatini DM. 2012. Ragulator is a GEF for the rag GTPases that signal amino acid levels to mTORC1. Cell 150: $1196-1208$.

Batista PJ, Chang HY. 2013. Long noncoding RNAs: Cellular address codes in development and disease. Cell 152: 1298-1307.

Baumeister W, Steven AC. 2000. Macromolecular electron microscopy in the era of structural genomics. Trends Biochem Sci 25: 624-631.

Beauchamp KA, McGibbon R, Lin YS, Pande VS. 2012. Simple few-state models reveal hidden complexity in protein folding. Proc Natl Acad Sci 109: 17807-17813.

Bendall SC, Simonds EF, Qiu P, Amir el-AD, Krutzik PO, Finck R, Bruggner RV, Melamed R, Trejo A, Ornatsky OI, et al. 2011. Singlecell mass cytometry of differential immune and drug responses across a human hematopoietic continuum. Science 332: 687-696.

Bensimon A, Heck AJ, Aebersold R. 2012. Mass spectrometry-based proteomics and network biology. Annu Rev Biochem 81: 379-405.

Berndt N, Hamilton AD, Sebti SM. 2011. Targeting protein prenylation for cancer therapy. Nat Rev Cancer 11: 775-791.

Bessman NJ, Lemmon MA. 2012. Finding the missing links in EGFR. Nat Struct Mol Biol 19: 1-3.

Bhattacharyya RP, Reményi A, Yeh BJ, Lim WA. 2006. Domains, motifs, and scaffolds: The role of modular interactions in the evolution and wiring of cell signaling circuits. Annu Rev Biochem 75: 655-680.

Blanchetot C, Chagnon M, Dubé N, Hallé M, Tremblay ML. 2005. Substrate-trapping techniques in the identification of cellular PTP targets. Methods 35: 44-53.

Blount BA, Weenink T, Ellis T. 2012. Construction of synthetic regulatory networks in yeast. FEBS Lett 586: 2112-2121.

Bodenmiller B, Zunder ER, Finck R, Chen TJ, Savig ES, Bruggner RV, Simonds EF, Bendall SC, Sachs K, Krutzik PO, et al. 2012. Multiplexed mass cytometry profiling of cellular states perturbed by small-molecule regulators. Nat Biotechnol 30: 858-867. 
Borrmann A, Milles S, Plass T, Dommerholt J, Verkade JM, Wiessler M, Schultz C, van Hest JC, van Delft FL, Lemke EA. 2012. Genetic encoding of a bicyclo[6.1.0] nonyne-charged amino acid enables fast cellular protein imaging by metal-free ligation. Chembiochem 13: 2094-2099.

Boström P, Wu J, Jedrychowski MP, Korde A, Ye L, Lo JC, Rasbach KA, Boström EA, Choi JH, Long JZ, et al. 2012. A PGC1- $\alpha$-dependent myokine that drives brown-fat-like development of white fat and thermogenesis. Nature 481: 463-468.

Boubekeur S, Boute N, Pagesy P, Zilberfarb V, Christeff M, Issad T. 2011. A new highly efficient substrate-trapping mutant of protein tyrosine phosphatase 1B (PTP1B) reveals full autoactivation of the insulin receptor precursor. J Biol Chem 286: 19373-19380.

Bradshaw JM. 2010. The Src, Syk, and Tec family kinases: Distinct types of molecular switches. Cell Signal 22: 1175-1184.

Briscoe J, Thérond PP. 2013. The mechanisms of Hedgehog signalling and its roles in development and disease. Nat Rev Mol Cell Biol 14: $416-429$.

Brooks BR, Brooks CL III, Mackerell ADJ, Nilsson L, Petrella RJ, Roux B, Won Y, Archontis G, Bartels C, Boresch S, et al. 2009. CHARMM: The biomolecular simulation program. J Comput Chem 30: 1545-1614.

Burrill DR, Boyle PM, Silver PA. 2011. A new approach to an old problem: Synthetic biology tools for human disease and metabolism. Cold Spring Harb Symp Quant Biol 76: 145-154.

Butko MT, Yang J, Geng Y, Kim HJ, Jeon NL, Shu X, Mackey MR, Ellisman MH, Tsien RY, Lin MZ. 2012. Fluorescent and photo-oxidizing TimeSTAMP tags track protein fates in light and electron microscopy. Nat Neurosci 15: 1742-1751.

Carroll D. 2011. Genome engineering with zinc-finger nucleases. Genetics 188: $773-782$.

Chakraborty AK, Das J. 2010. Pairing computation with experimentation: A powerful coupling for understanding T cell signalling. Nat Rev Immunol 19: 59-71.

Chalfie M, Tu Y, Euskirchen G, Ward WW, Prasher DC. 1994. Green fluorescent protein as a marker for gene expression. Science 263: 802-805.

Cheong R, Wang CJ, Levchenko A. 2009. Using a microfluidic device for high-content analysis of cell signaling. Sci Signal 2: pl2.1-pl2.18.

Chi A, Huttenhower C, Geer LY, Coon JJ, Syka JE, Bai DL, Shabanowitz J, Burke DJ, Troyanskaya OG, Hunt DF. 2007. Analysis of phosphorylation sites on proteins from Saccharomyces cerevisiae by electron transfer dissociation (ETD) mass spectrometry. Proc Natl Acad Sci 104: 2193-2198.

Chin JW. 2014. Expanding and reprogramming the genetic code of cells and animals. Annu Rev Biochem doi: 10.1146/annurev-biochem060713-035737.

Chin KH, Tu ZL, Su YC, Yu YJ, Chen HC, Lo YC, Chen CP, Barber GN, Chuah ML, Liang ZX, et al. 2013. Novel c-di-GMP recognition modes of the mouse innate immune adaptor protein STING. Acta Crystallogr D Biol Crystallogr 69: 352-366.

Chiu W, Baker ML, Almo SC. 2006. Structural biology of cellular machines. Trends Cell Biol 16: 144-150.

Choi DS, Kim DK, Kim YK, Gho YS. 2013. Proteomics, transcriptomics and lipidomics of exosomes and ectosomes. Proteomics 13: 15541571.

Christie JM, Gawthorne J, Young G, Fraser NJ, Roe AJ. 2012. LOV to BLUF: Flavoprotein contributions to the optogenetic toolkit. Mol Plant 5: 533-544.

Civelli O. 2012. Orphan GPCRs and neuromodulation. Neuron 76: $12-21$.

Close DM, Xu T, Sayler GS, Ripp S. 2011. In vivo bioluminescent imaging (BLI): Noninvasive visualization and interrogation of biological processes in living animals. Sensors 11: 180-206.

Coelho M, Maghelli N, Tolic-Nørrelykke IM. 2013. Single-molecule imaging in vivo: The dancing building blocks of the cell. Integr Biol 5: $748-758$.
Cohen P. 1992. Signal integration at the level of protein kinases, protein phosphatases and their substrates. Trends Biochem Sci 17: 408-413.

Cohen P. 2002. The origins of protein phosphorylation. Nat Cell Biol 4: E127-E130.

Cohen P, Alessi DR. 2013. Kinase drug discovery-What's next in the field? ACS Chem Biol 8: 96-104.

Cohen P, Knebel A. 2006. KESTREL: A powerful method for identifying the physiological substrates of protein kinases. Biochem J 393: 1-6.

Cook JG, Bardwell L, Kron SJ, Thorner J. 1996. Two novel targets of the MAP kinase Kss1 are negative regulators of invasive growth in the yeast Saccharomyces cerevisiae. Genes Dev 10: 2831-2848.

Copley RR, Doerks T, Letunic I, Bork P. 2002. Protein domain analysis in the era of complete genomes. FEBS Lett 513: 129-134.

Corrêa IR Jr, Baker B, Zhang A, Sun L, Provost CR, Lukinavicius G, Reymond L, Johnsson K, Xu MQ. 2013. Substrates for improved live-cell fluorescence labeling of SNAP-tag. Curr Pharm Des 19: 5414-5420.

Crabtree GR, Schreiber SL. 1996. Three-part inventions: Intracellular signaling and induced proximity. Trends Biochem Sci 21: 418-422.

Creanga A, Glenn TD, Mann RK, Saunders AM, Talbot WS, Beachy PA. 2012. Scube/You activity mediates release of dually lipid-modified Hedgehog signal in soluble form. Genes Dev 26: 1312-1325.

Dang L, White DW, Gross S, Bennett BD, Bittinger MA, Driggers EM, Fantin VR, Jang HG, Jin S, Keenan MC, et al. 2009. Cancer-associated IDH1 mutations produce 2-hydroxyglutarate. Nature 462: 739-744.

Da Prada M, Pletscher A, Tranzer JP. 1971. Storage of ATP and 5hydroxytryptamine in blood platelets of guinea-pigs. J Physiol 217: 679-688.

Dbouk HA, Vadas O, Williams RL, Backer JM. 2012. PI3K $\beta$ downstream of GPCRs-Crucial partners in oncogenesis. Oncotarget 3: 14851486.

Debets MF, van Hest JC, Rutjes FP. 2013. Bioorthogonal labelling of biomolecules: New functional handles and ligation methods. Org Biomol Chem 11: 6439-6455.

de Lecea L, Kilduff TS, Peyron C, Gao X, Foye PE, Danielson PE, Fukuhara C, Battenberg EL, Gautvik VT, Bartlett FS, et al. 1998. The hypocretins: Hypothalamus-specific peptides with neuroexcitatory activity. Proc Natl Acad Sci 95: 322-327.

Dennis EA, Cao J, Hsu YH, Magrioti V, Kokotos G. 2011. Phospholipase $\mathrm{A}_{2}$ enzymes: Physical structure, biological function, disease implication, chemical inhibition, and therapeutic intervention. Chem Rev 111: $6130-6185$.

Deshaies RJ, Emberley ED, Saha A. 2010. Control of cullin-ring ubiquitin ligase activity by nedd8. Subcell Biochem 54: 41-56.

Dewey CN, Pachter L. 2006. Evolution at the nucleotide level: The problem of multiple whole-genome alignment. Hum Mol Genet 15: R51R56.

Diner EJ, Burdette DL, Wilson SC, Monroe KM, Kellenberger CA, Hyodo M, Hayakawa Y, Hammond MC, Vance RE. 2013. The innate immune DNA sensor cGAS produces a noncanonical cyclic dinucleotide that activates human STING. Cell Rep 3: 1355-1361.

Doolittle RF. 1995. The multiplicity of domains in proteins. Annu Rev Biochem 64: 287-314.

Dou Z, Pan JA, Dbouk HA, Ballou LM, DeLeon JL, Fan Y, Chen JS, Liang Z, Li G, Backer JM, et al. 2013. Class IA PI3K p110ß subunit promotes autophagy through Rab5 small GTPase in response to growth factor limitation. Mol Cell 50: 29-42.

Dror RO, Dirks RM, Grossman JP, Xu H, Shaw DE. 2012. Biomolecular simulation: A computational microscope for molecular biology. Annu Rev Biophys 41: 429-452.

Duncan JS, Whittle MC, Nakamura K, Abell AN, Midland AA, Zawistowski JS, Johnson NL, Granger DA, Jordan NV, Darr DB, et al. 2012. Dynamic reprogramming of the kinome in response to targeted MEK inhibition in triple-negative breast cancer. Cell 149: 307-321.

Dunker AK, Silman I, Uversky VN, Sussman JL. 2008. Function and structure of inherently disordered proteins. Curr Opin Struct Biol 18: $756-764$. 
* Duronio RJ, Xiong Y. 2013. Signaling pathways that control cell proliferation. Cold Spring Harb Perspect Biol 5: a008904.

Elphick LM, Lee SE, Gouverneur V, Mann DJ. 2007. Using chemical genetics and ATP analogues to dissect protein kinase function. ACS Chem Biol 2: 299-314.

Encell LP, Friedman Ohana R, Zimmerman K, Otto P, Vidugiris G, Wood MG, Los GV, McDougall MG, Zimprich C, Karassina N, et al. 2012. Development of a dehalogenase-based protein fusion tag capable of rapid, selective and covalent attachment to customizable ligands. Curr Chem Genomics 6: 55-71.

Endicott JA, Noble MA, Johnson LN. 2012. The structural basis for control of eukaryotic protein kinases. Annu Rev Biochem 81: 587-613.

Endres NF, Das R, Smith AW, Arkhipov A, Kovacs E, Huang Y, Pelton JG, Shan Y, Shaw DE, Wemmer DE, et al. 2013. Conformational coupling across the plasma membrane in activation of the EGF receptor. Cell 152: $543-556$.

Engholm-Keller K, Larsen MR. 2013. Technologies and challenges in large-scale phosphoproteomics. Proteomics 13: 910-931.

English JM, Cobb MH. 2002. Pharmacological inhibitors of MAPK pathways. Trends Pharmacol Sci 23: 40-45.

Erickson HP. 2013. Irisin and FNDC5 in retrospect: An exercise hormone or a transmembrane receptor? Adipocyte 2: 289-293.

Farley AR, Link AJ. 2009. Identification and quantification of protein posttranslational modifications. Methods Enzymol 463: 725-763.

Farrar MA, Alberol-Ila J, Perlmutter RM. 1996. Activation of the Raf-1 kinase cascade by coumermycin-induced dimerization. Nature 383: $178-181$.

Feldman ME, Shokat KM. 2010. New inhibitors of the PI3K-Akt-mTOR pathway: Insights into mTOR signaling from a new generation of Tor kinase domain inhibitors (TORKinibs). Curr Top Microbiol Immunol 347: $241-262$.

Fenno L, Yizhar O, Deisseroth K. 2011. The development and application of optogenetics. Annu Rev Neurosci 34: 389-412.

Ferrell JE Jr. 2000. What do scaffold proteins really do? Sci STKE 2000: e1.

Filonov GS, Verkhusha VV. 2013. A near-infrared BiFC reporter for in vivo imaging of protein-protein interactions. Chem Biol 20: 10781086.

Fischer EH. 2013. Cellular regulation by protein phosphorylation. Biochem Biophys Res Commun 430: 865-867.

Florey O, Overholtzer M. 2012. Autophagy proteins in macroendocytic engulfment. Trends Cell Biol 22: 374-380.

Frame S, Cohen P. 2001. GSK3 takes centre stage more than 20 years after its discovery. Biochem J 359: 1-16.

Frank J. 2009. Single-particle reconstruction of biological macromolecules in electron microscopy-30 years. Q Rev Biophys 42: 139-158.

Freed-Pastor WA, Prives C. 2012. Mutant p53: One name, many proteins. Genes Dev 26: 1268-1286.

Freeman RS, Hasbani DM, Lipscomb EA, Straub JA, Xie L. 2003. SM-20, EGL-9, and the EGLN family of hypoxia-inducible factor prolyl hydroxylases. Mol Cells 16: 1-12.

Friedland GD, Kortemme T. 2010. Designing ensembles in conformational and sequence space to characterize and engineer proteins. Curr Opin Struct Biol 20: 377-384.

Fukada M, Noda M. 2007. Yeast substrate-trapping system for isolating substrates of protein tyrosine phosphatases. Methods $\mathrm{Mol}$ Biol 365: $371-382$.

Gaj T, Gersbach CA, Barbas CF III. 2013. ZFN, TALEN, and CRISPR/ Cas-based methods for genome engineering. Trends Biotechnol 31: 397-405.

Galperin MY, Koonin EV. 2012. Divergence and convergence in enzyme evolution. J Biol Chem 287: 21-28.

Gao X, Wang H, Yang JJ, Liu X, Liu ZR. 2012. Pyruvate kinase M2 regulates gene transcription by acting as a protein kinase. Mol Cell 45: 598-609.

Garcia-Gonzalo FR, Reiter JF. 2012. Scoring a backstage pass: Mechanisms of ciliogenesis and ciliary access. J Cell Biol 197: 697-709.
Gautier A, Juillerat A, Heinis C, Corrêa IRJ, Kindermann M, Beaufils F, Johnsson K. 2008. An engineered protein tag for multiprotein labeling in living cells. Chem Biol 15: 128-136.

Gevaert K, Vandekerckhove J. 2009. Reverse-phase diagonal chromatography for phosphoproteome research. Methods Mol Biol 527: 219-227.

Ghosh M, Tucker DE, Burchett SA, Leslie CC. 2006. Properties of the Group IV phospholipase $\mathrm{A}_{2}$ family. Prog Lipid Res 45: 487-510.

Goldsmith EJ, Akella R, Min X, Zhou T, Humphreys JM. 2007. Substrate and docking interactions in serine/threonine protein kinases. Chem Rev 107: 5065-5081.

González-Vera JA. 2012. Probing the kinome in real time with fluorescent peptides. Chem Soc Rev 41: 1652-1664.

Goodenough DA, Paul DL. 2009. Gap junctions. Cold Spring Harb Perspect Biol 1: a002576.

Gorostiza P, Isacoff EY. 2008. Optical switches for remote and noninvasive control of cell signaling. Science 322: 395-399.

Granier S, Kobilka B. 2012. A new era of GPCR structural and chemical biology. Nat Chem Biol 8: 670-673.

Greco V, Hannus M, Eaton S. 2001. Argosomes: A potential vehicle for the spread of morphogens through epithelia. Cell 106: 633-645.

Greenleaf WJ, Woodside MT, Block SM. 2007. High-resolution, singlemolecule measurements of biomolecular motion. Annu Rev Biophys Biomol Struct 36: 171-190.

Groves JT, Kuriyan J. 2010. Molecular mechanisms in signal transduction at the membrane. Nat Struct Mol Biol 17: 659-665.

Guerra C, Barbacid M. 2013. Genetically engineered mouse models of pancreatic adenocarcinoma. Mol Oncol 7: 232-247.

Guerrero G, Isacoff EY. 2001. Genetically encoded optical sensors of neuronal activity and cellular function. Curr Opin Neurobiol 11: 601-607.

Guibert S, Weber M. 2013. Functions of DNA methylation and hydroxymethylation in mammalian development. Curr Top Dev Biol 104: $47-83$.

Hancks DC, Kazazian HHJ. 2012. Active human retrotransposons: Variation and disease. Curr Opin Genet Dev 22: 191-203.

* Hardie DG. 2012. Organismal carbohydrate and lipid homeostasis. Cold Spring Harb Perspect Biol 4: a006031.

Hart GW, Slawson C, Ramirez-Correa G, Lagerlof O. 2011. Cross talk between O-GlcNAcylation and phosphorylation: Roles in signaling, transcription, and chronic disease. Annu Rev Biochem 80: 825-858.

Harvey CD, Ehrhardt AG, Cellurale C, Zhong H, Yasuda R, Davis RJ, Svoboda K. 2008. A genetically encoded fluorescent sensor of ERK activity. Proc Natl Acad Sci 105: 19264-19269.

* Hemmings BA, Restuccia DF. 2012. PI3K-PKB/Akt pathway. Cold Spring Harb Perspect Biol 4: a011189.

Herner A, Nikic I, Kállay M, Lemke EA, Kele P. 2013. A new family of bioorthogonally applicable fluorogenic labels. Org Biomol Chem 11: 3297-3306.

Hertz NT, Wang BT, Allen JJ, Zhang C, Dar AC, Burlingame AL, Shokat KM. 2010. Chemical genetic approach for kinase-substrate mapping by covalent capture of thiophosphopeptides and analysis by mass spectrometry. Curr Protoc Chem Biol 2: 15-36.

Higashii T, Isomoto A, Tyuma I, Kakishita E, Uomoto M, Nagai K. 1985. Quantitative and continuous analysis of ATP release from blood platelets with firefly luciferase luminescence. Thromb Haemost 53: $65-69$.

Hitosugi T, Kang S, Vander Heiden MG, Chung TW, Elf S, Lythgoe K, Dong S, Lonial S, Wang Z, Chen GZ, et al. 2009. Tyrosine phosphorylation inhibits PKM2 to promote the Warburg effect and tumor growth. Sci Signal 2: ra73.71-ra73.78.

Horiuchi K. 2013. A brief history of tumor necrosis factor $\alpha$-converting enzyme: An overview of ectodomain shedding. Keio J Med 62: 29-36.

Hou H, Yu H. 2010. Structural insights into histone lysine demethylation. Curr Opin Struct Biol 20: 739-748. 
Hou F, Sun L, Zheng H, Skaug B, Jiang QX, Chen ZJ. 2011. MAVS forms functional prion-like aggregates to activate and propagate antiviral innate immune response. Cell 146: 448-461.

Howard AD, Feighner SD, Cully DF, Arena JP, Liberator PA, Rosenblum CI, Hamelin M, Hreniuk DL, Palyha OC, Anderson J, et al. 1996. A receptor in pituitary and hypothalamus that functions in growth hormone release. Science 273: 974-977.

Huang B, Bates M, Zhuang X. 2009. Super-resolution fluorescence microscopy. Апnu Rev Biochem 78: 993-1016.

Huang IK, Pei J, Grishin NV. 2013. Defining and predicting structurally conserved regions in protein superfamilies. Bioinformatics 29: $175-181$.

Hunter T. 2012. Why nature chose phosphate to modify proteins. Philos Trans R Soc Lond B Biol Sci 367: 2513-2516.

* Ingham PW. 2012. Hedgehog signaling. Cold Spring Harb Perspect Biol 4: a011221.

Isse N, Ogawa Y, Tamura N, Masuzaki H, Mori K, Okazaki T, Satoh N, Shigemoto M, Yoshimasa Y, Nishi S, et al. 1995. Structural organization and chromosomal assignment of the human obese gene. J Biol Chem 270: 27728-27733.

Janes KA, Lauffenburger DA. 2013. Models of signalling networksWhat cell biologists can gain from them and give to them. J Cell Sci 126: $1913-1921$

Jeffery CJ. 2009. Moonlighting proteins-An update. Mol Biosyst 5: $345-350$.

Jiang Z, Rokhsar DS, Harland RM. 2009. Old can be new again: HAPPY whole genome sequencing, mapping and assembly. Int J Biol Sci 5: $298-303$.

Jin J, Pawson T. 2012. Modular evolution of phosphorylation-based signalling systems. Philos Trans R Soc Lond B Biol Sci 367: 2540-2555.

Joerger AC, Fersht AR. 2008. Structural biology of the tumor suppressor p53. Annu Rev Biochem 77: 557-582.

Jura N, Zhang X, Endres NF, Seeliger MA, Schindler T, Kuriyan J. 2011. Catalytic control in the EGF receptor and its connection to general kinase regulatory mechanisms. Mol Cell 42: 9-22.

Kalia D, Merey G, Nakayama S, Zheng Y, Zhou J, Luo Y, Guo M, Roembke BT, Sintim HO. 2013. Nucleotide, c-di-GMP, c-di-AMP, cGMP, cAMP, (p)ppGpp signaling in bacteria and implications in pathogenesis. Chem Soc Rev 42: 305-341.

Kang JY, Kawaguchi D, Coin I, Xiang Z, O’Leary DD, Slesinger PA, Wang L. 2013. In vivo expression of a light-activatable potassium channel using unnatural amino acids. Neuron 80: 358-370.

Katritch V, Cherezov V, Stevens RC. 2013. Structure-function of the G protein-coupled receptor superfamily. Annu Rev Pharmacol Toxicol 53: $531-556$

Kerppola TK. 2009. Visualization of molecular interactions using bimolecular fluorescence complementation analysis: Characteristics of protein fragment complementation. Chem Soc Rev 38: 2876-2886.

Khakh BS, North RA. 2012. Neuromodulation by extracellular ATP and P2X receptors in the CNS. Neuron 76: 51-69.

Kiu H, Nicholson SE. 2012. Biology and significance of the JAK/STAT signalling pathways. Growth Factors 30: 88-106.

Kleiman LB, Maiwald T, Conzelmann H, Lauffenburger DA, Sorger PK. 2011. Rapid phospho-turnover by receptor tyrosine kinases impacts downstream signaling and drug binding. Mol Cell 43: 723-737.

Kliegman JI, Fiedler D, Ryan CJ, Xu YF, Su XY, Thomas D, Caccese MC, Cheng A, Shales M, Rabinowitz JD, et al. 2013. Chemical genetics of rapamycin-insensitive TORC2 in S. cerevisiae. Cell Rep 5: 1725-1736.

Knight ZA, Shokat KM. 2007. Chemical genetics: Where genetics and pharmacology meet. Cell 128: 425-430.

Knight JD, Pawson T, Gingras AC. 2013. Profiling the kinome: Current capabilities and future challenges. J Proteomics 81: 43-55.

Knighton DR, Zheng JH, Ten Eyck LF, Ashford VA, Xuong NH, Taylor SS, Sowadski JM. 1991. Crystal structure of the catalytic subunit of cyclic adenosine monophosphate-dependent protein kinase. Science 253: $407-414$
Kõivomägi M, Valk E, Venta R, Iofik A, Lepiku M, Balog ER, Rubin SM, Morgan DO, Loog M. 2011. Cascades of multisite phosphorylation control Sicl destruction at the onset of S phase. Nature 480: 128-131.

Kojima M, Hosoda H, Date Y, Nakazato M, Matsuo H, Kangawa K. 1999. Ghrelin is a growth-hormone-releasing acylated peptide from stomach. Nature 402: 656-660.

Kolb P, Ferreira RS, Irwin JJ, Shoichet BK. 2009. Docking and chemoinformatic screens for new ligands and targets. Curr Opin Biotechnol 20: $429-436$.

Kramer RH, Mourot A, Adesnik H. 2013. Optogenetic pharmacology for control of native neuronal signaling proteins. Nat Neurosci 16: $816-$ 823.

Kranzusch PJ, Lee AS, Berger JM, Doudna JA. 2013. Structure of human cGAS reveals a conserved family of second-messenger enzymes in innate immunity. Cell Rep 3: 1362-1368.

Krishna RG, Wold F. 1993. Post-translational modification of proteins. Adv Enzymol Relat Areas Mol Biol 67: 265-298.

Kumar J, Mayer ML. 2013. Functional insights from glutamate receptor ion channel structures. Annu Rev Physiol 75: 313-337.

Kunkel MT, Toker A, Tsien RY, Newton AC. 2007. Calcium-dependent regulation of protein kinase $\mathrm{D}$ revealed by a genetically encoded kinase activity reporter. J Biol Chem 282: 6733-6742.

Kuriyan J, Eisenberg D. 2007. The origin of protein interactions and allostery in colocalization. Nature 450: 983-990.

Lander GC, Saibil HR, Nogales E. 2012. Go hybrid: EM, crystallography, and beyond. Curr Opin Struct Biol 22: 627-635.

Lane TJ, Shukla D, Beauchamp KA, Pande VS. 2013. To milliseconds and beyond: Challenges in the simulation of protein folding. Curr Opin Struct Biol 23: 58-65.

Lassila JK, Zalatan JG, Herschlag D. 2011. Biological phosphoryl-transfer reactions: Understanding mechanism and catalysis. Annu Rev Biochem 80: $669-702$.

Lau SY, Procko E, Gaudet R. 2012. Distinct properties of $\mathrm{Ca}^{2+}$-calmodulin binding to $\mathrm{N}$ - and C-terminal regulatory regions of the TRPV1 channel. J Gen Physiol 140: 541-555.

* Lee M, Yaffe MB. 2014. Protein regulation in signal transduction. Cold Spring Harb Perspect Biol doi: 10.1101/cshperspect.a005918.

Leitner A, Sturm M, Lindner W. 2011. Tools for analyzing the phosphoproteome and other phosphorylated biomolecules. Anal Chim Acta 703: $19-30$.

Leivar P, Quail PH. 2011. PIFs: Pivotal components in a cellular signaling hub. Trends Plant Sci 16: 19-28.

Levskaya A, Weiner OD, Lim WA, Voigt CA. 2009. Spatiotemporal control of cell signalling using a light-switchable protein interaction. Nature 461: 997-1001.

Li M, Yu Y, Yang J. 2011. Structural biology of TRP channels. Adv Exp Med Biol 704: 1-23.

Lim JH, Kim HJ, Komatsu K, Ha U, Huang Y, Jono H, Kweon SM, Lee J, Xu X, Zhang GS, et al. 2009. Differential regulation of Streptococcus pneumoniae-induced human MUC5AC mucin expression through distinct MAPK pathways. Am J Transl Res 1: 300-311.

Lim WA, Lee CM, Tang C. 2013. Design principles of regulatory networks: Searching for the molecular algorithms of the cell. Mol Cell 49: $202-212$.

Lima SQ, Miesenböck G. 2005. Remote control of behavior through genetically targeted photostimulation of neurons. Cell 121: 141-152.

Lin H, Su X, He B. 2012. Protein lysine acylation and cysteine succination by intermediates of energy metabolism. ACS Chem Biol 7: 947-960.

Lin R, Tao R, Gao X, Li T, Zhou X, Guan KL, Xiong Y, Lei QY. 2013. Acetylation stabilizes ATP-citrate lyase to promote lipid biosynthesis and tumor growth. Mol Cell 51: 506-518.

Liu CC, Schultz PG. 2010. Adding new chemistries to the genetic code. Annu Rev Biochem 79: 413-444.

Londoño Gentile T, Lu C, Lodato PM, Tse S, Olejniczak SH, Witze ES, Thompson CB, Wellen KE. 2013. DNMT1 is regulated by ATP-citrate 
lyase and maintains methylation patterns during adipocyte differentiation. Mol Cell Biol 33: 3864-3878.

Loroch S, Dickhut C, Zahedi RP, Sickmann A. 2013. Phosphoproteomics-More than meets the eye. Electrophoresis 34: 1483-1492.

Losman JA, Kaelin WG Jr. 2013. What a difference a hydroxyl makes: Mutant IDH, (R)-2-hydroxyglutarate, and cancer. Genes Dev 27: $836-852$.

Lowery DM, Lim D, Yaffe MB. 2005. Structure and function of Polo-like kinases. Oncogene 24: 248-259.

Luo W, Hu H, Chang R, Zhong J, Knabel M, O’Meally R, Cole RN, Pandey A, Semenza GL. 2011. Pyruvate kinase M2 is a PHD3-stimulated coactivator for hypoxia-inducible factor 1. Cell 145: 732-744.

MacKinnon R. 2003. Potassium channels. FEBS Lett 555: 62-65.

Malone JH, Oliver B. 2011. Microarrays, deep sequencing and the true measure of the transcriptome. BMC Biol 9: 34.31-34.39.

Marks LR, Davidson BA, Knight PR, Hakansson AP. 2013. Interkingdom signaling induces Streptococcus pneumoniae biofilm dispersion and transition from asymptomatic colonization to disease. mBio 4: e00438-13.

Martell JD, Deerinck TJ, Sancak Y, Poulos TL, Mootha VK, Sosinsky GE, Ellisman MH, Ting AY. 2012. Engineered ascorbate peroxidase as a genetically encoded reporter for electron microscopy. Nat Biotechnol 30: $1143-1148$.

Martinez NJ, Gregory RI. 2010. MicroRNA gene regulatory pathways in the establishment and maintenance of ESC identity. Cell Stem Cell 7: $31-35$.

McGettigan PA. 2013. Transcriptomics in the RNA-seq era. Curr Opin Chem Biol 17: 4-11.

Mendell JT, Olson EN. 2012. MicroRNAs in stress signaling and human disease. Cell 148: 1172-1187.

Miller G. 2006. Optogenetics. Shining new light on neural circuits. Science 314: 1674-1676.

Miller EW, Lin JY, Frady EP, Steinbach PA, Kristan WB Jr, Tsien RY. 2012. Optically monitoring voltage in neurons by photo-induced electron transfer through molecular wires. Proc Natl Acad Sci 109: 2114-2119.

Miller RM, Paavilainen VO, Krishnan S, Serafimova IM, Taunton J. 2013. Electrophilic fragment-based design of reversible covalent kinase inhibitors. J Am Chem Soc 135: 5298-5301.

Miyawaki A. 2002. Green fluorescent protein-like proteins in reef Anthozoa animals. Cell Struct Funct 27: 343-347.

Miyawaki A. 2011. Development of probes for cellular functions using fluorescent proteins and fluorescence resonance energy transfer. Annu Rev Biochem 80: 357-373.

Moffitt JR, Chemla YR, Smith SB, Bustamante C. 2008. Recent advances in optical tweezers. Annu Rev Biochem 77: 205-228.

Monda JK, Scott DC, Miller DJ, Lydeard J, King D, Harper JW, Bennett EJ, Schulman BA. 2013. Structural conservation of distinctive Nterminal acetylation-dependent interactions across a family of mammalian NEDD8 ligation enzymes. Structure 21: 42-53.

Morgan DO. 2007. The cell cycle: Principles of control. New Science, London.

Moro E, Vettori A, Porazzi P, Schiavone M, Rampazzo E, Casari A, Ek O, Facchinello N, Astone M, Zancan I, et al. 2013. Generation and application of signaling pathway reporter lines in zebrafish. Mol Genet Genomics 288: 231-242.

* Morrison DK. 2012. MAP kinase pathways. Cold Spring Harb Perspect Biol 4: a011254.

Mulvihill MM, Nomura DK. 2013. Therapeutic potential of monoacylglycerol lipase inhibitors. Life Sci 92: 492-497.

Musacchio A, Noble M, Pauptit R, Wierenga R, Saraste M. 1992. Crystal structure of a Src-homology 3 (SH3) domain. Nature 359: 851-855.

Mutoh H, Perron A, Akemann W, Iwamoto Y, Knöpfel T. 2011. Optogenetic monitoring of membrane potentials. Exp Physiol 96: 13-18.

Nardella C, Carracedo A, Salmena L, Pandolfi PP. 2010. Faithfull modeling of PTEN loss-driven diseases in the mouse. Curr Top Microbiol Immunol 347: 135-168.
Nash PD. 2012. Why modules matter. FEBS Lett 586: 2572-2574.

Nash P, Tang X, Orlicky S, Chen Q, Gertler FB, Mendenhall MD, Sicheri F, Pawson T, Tyers M. 2001. Multisite phosphorylation of a CDK inhibitor sets a threshold for the onset of DNA replication. Nature 414: $514-521$

Newell EW, Sigal N, Nair N, Kidd BA, Greenberg HB, Davis MM. 2013. Combinatorial tetramer staining and mass cytometry analysis facilitate T-cell epitope mapping and characterization. Nat Biotechnol 31: $623-629$.

Niu W, Guo J. 2013. Expanding the chemistry of fluorescent protein biosensors through genetic incorporation of unnatural amino acids. Mol Biosyst 9: 2961-2970.

Nozawa YI, Lin C, Chuang PT. 2013. Hedgehog signaling from the primary cilium to the nucleus: An emerging picture of ciliary localization, trafficking and transduction. Curr Opin Genet Dev 23: 429-437.

Otsubo Y, Yamamato M. 2008. TOR signaling in fission yeast. Crit Rev Biochem Mol Biol 43: 277-283.

Overholtzer M, Mailleux AA, Mouneimne G, Normand G, Schnitt SJ, King RW, Cibas ES, Brugge JS. 2007. A nonapoptotic cell death process, entosis, that occurs by cell-in-cell invasion. Cell 131: 966-979.

Palumbo AM, Smith SA, Kalcic CL, Dantus M, Stemmer PM, Reid GE. 2011. Tandem mass spectrometry strategies for phosphoproteome analysis. Mass Spectrom Rev 30: 600-625.

Parzych KR, Klionsky D. 2014. An overview of autophagy: Morphology, mechanism and regulation. Antioxid Redox Signal 20: 460-473.

Patricelli MP, Szardenings AK, Liyanage M, Nomanbhoy TK, Wu M, Weissig H, Aban A, Chun D, Tanner S, Kozarich JW. 2007. Functional interrogation of the kinome using nucleotide acyl phosphates. Biochemistry 46: 350-358.

Pawson T, Nash P. 2003. Assembly of cell regulatory systems through protein interaction domains. Science 300: 445-452.

Pearen MA, Muscat GE. 2012. Orphan nuclear receptors and the regulation of nutrient metabolism: Understanding obesity. Physiology 27: $156-166$.

* Perrimon N, Pitsouli C, Shilo BZ. 2012. Signaling mechanisms controlling cell fate and embryonic patterning. Cold Spring Harb Perspect Biol 4: a005975.

Piatkevich KD, Verkhusha VV. 2010. Advances in engineering of fluorescent proteins and photoactivatable proteins with red emission. Curr Opin Chem Biol 14: 23-29.

Piatkevich KD, Subach FV, Verkhusha VV. 2013. Engineering of bacterial phytochromes for near-infrared imaging, sensing, and light-control in mammals. Chem Soc Rev 42: 3441-3452.

Pluznick JL, Protzko RJ, Gevorgyan H, Peterlin Z, Sipos A, Han J, Brunet I, Wan LX, Rey F, Wang T, et al. 2013. Olfactory receptor responding to gut microbiota-derived signals plays a role in renin secretion and blood pressure regulation. Proc Natl Acad Sci 110: 4410-4415.

Portnoy DA. 2012. Yogi Berra, Forrest Gump, and the discovery of Listeria actin comet tails. Mol Biol Cell 23: 1141-1145.

Pryciak PM. 2009. Designing new cellular signaling pathways. Chem Biol 16: $249-254$.

Ptacek J, Snyder M. 2006. Charging it up: Global analysis of protein phosphorylation. Trends Genet 22: 545-554.

Racey LA, Byvoet P. 1971. Histone acetyltransferase in chromatin. Evidence for in vitro enzymatic transfer of acetate from acetyl-coenzyme A to histones. Exp Cell Res 64: 366-370.

Rasmussen SG, DeVree BT, Zou Y, Kruse AC, Chung KY, Kobilka TS, Thian FS, Chae PS, Pardon E, Calinski D, et al. 2011. Crystal structure of the $\beta_{2}$ adrenergic receptor-Gs protein complex. Nature 477: 549 555.

Ravnskjaer K, Hogan MF, Lackey D, Tora L, Dent SY, Olefsky J, Montminy M. 2013. Glucagon regulates gluconeogenesis through KAT2B- and WDR5-mediated epigenetic effects. J Clin Invest 123: 4318-4328.

Reményi A, Good MC, Lim WA. 2006. Docking interactions in protein kinase and phosphatase networks. Curr Opin Struct Biol 16: 676-685. 
Renicke C, Schuster D, Usherenko S, Essen LO, Taxis C. 2013. A LOV2 domain-based optogenetic tool to control protein degradation and cellular function. Chem Biol 20: 619-626.

Resh MD. 2012. Targeting protein lipidation in disease. Trends Mol Med 18: $206-214$.

* Rhind N, Russell P. 2012. Signaling pathways that regulate cell division. Cold Spring Harb Perspect Biol 4: a005942.

Rockwell NC, Su YS, Lagarias JC. 2006. Phytochrome structure and signaling mechanisms. Annu Rev Plant Biol 57: 837-858.

Rogne M, Taskén K. 2013. Cell signalling analyses in the functional genomics era. New Biotechnol 30: 333-338.

Roskoski RJ. 2012. MEK1/2 dual-specificity protein kinases: Structure and regulation. Biochem Biophys Res Commun 417: 5-10.

Roux PP, Thibault P. 2013. The coming of age of phosphoproteomicsFrom large data sets to inference of protein functions. Mol Cell Proteomics 12: 3453-3464.

Roy S, Hsiung F, Kornberg TB. 2011. Specificity of Drosophila cytonemes for distinct signaling pathways. Science 332: 354-358.

Rubakhin SS, Lanni EJ, Sweedler JV. 2013. Progress toward single cell metabolomics. Curr Opin Biotechnol 24: 95-104.

Sadikot RT, Blackwell TS. 2008. Bioluminescence: Imaging modality for in vitro and in vivo gene expression. Methods Mol Biol 477: 383-394.

Sadowski MI, Taylor WR. 2013. Prediction of protein contacts from correlated sequence substitutions. Sci Prog 96: 33-42.

Sadowsky JD, Burlingame MA, Wolan DW, McClendon CL, Jacobson MP, Wells JA. 2011. Turning a protein kinase on or off from a single allosteric site via disulfide trapping. Proc Nat Acad Sci 108: 60566061.

Sakurai T, Amemiya A, Ishii M, Matsuzaki I, Chemelli RM, Tanaka H, Williams SC, Richardson JA, Kozlowski GP, Wilson S, et al. 1998. Orexins and orexin receptors: A family of hypothalamic neuropeptides and $\mathrm{G}$ protein-coupled receptors that regulate feeding behavior. Cell 92: $573-585$.

Sanders TA, Llagostera E, Barna M. 2013. Specialized filopodia direct long-range transport of $\mathrm{SHH}$ during vertebrate tissue patterning. Nature 497: 628-632.

Savinainen JR, Saario SM, Laitinen JT. 2012. The serine hydrolases MAGL, ABHD6 and ABHD12 as guardians of 2-arachidonoylglycerol signalling through cannabinoid receptors. Acta Physiol 204: 267-276.

Scarpa ES, Fabrizio G, Di Girolamo M. 2013. A role of intracellular mono-ADP-ribosylation in cancer biology. FEBS J 280: 3551-3562.

Schmid JA, Birbach A. 2007. Fluorescent proteins and fluorescence resonance energy transfer (FRET) as tools in signaling research. Thromb Haemost 97: 378-384.

Schumacher MA, Chinnam N, Ohashi T, Shah RS, Erickson HP. 2013. The structure of irisin reveals a novel intersubunit $\beta$-sheet fibronectin type III (FNIII) dimer: Implications for receptor activation. J Biol Chem 288: $33738-33744$.

Sengupta P, Van Engelenburg S, Lippincott-Schwartz J. 2012. Visualizing cell structure and function with point-localization superresolution imaging. Dev Cell 23: 1092-1102.

Shaner NC, Lin MZ, McKeown MR, Steinbach PA, Hazelwood KL, Davidson MW, Tsien RY. 2008. Improving the photostability of bright monomeric orange and red fluorescent proteins. Nat Methods 5: $545-551$.

Shaw N, Liu ZJ. 2014. Role of the HIN domain in regulation of innate immune responses. Mol Cell Biol 34: 2-15.

Shendure J, Mitra RD, Varma C, Church GM. 2004. Advanced sequencing technologies: Methods and goals. Nat Rev Genet 5: 335-344.

Shu X, Royant A, Lin MZ, Aguilera TA, Lev-Ram V, Steinbach PA, Tsien RY. 2009. Mammalian expression of infrared fluorescent proteins engineered from a bacterial phytochrome. Science 324: 804-807.

Shu X, Lev-Ram V, Deerinck TJ, Qi Y, Ramko EB, Davidson MW, Jin Y, Ellisman MH, Tsien RY. 2011. A genetically encoded tag for correlated light and electron microscopy of intact cells, tissues, and organisms. PLoS Biol 9: e1001041.
Silverman JS, Skaar JR, Pagano M. 2012. SCF ubiquitin ligases in the maintenance of genome stability. Trends Biochem Sci 37: 66-73.

Sims RJ III, Reinberg D. 2008. Is there a code embedded in proteins that is based on post-translational modifications? Nat Rev Mol Cell Biol 9: $815-820$.

Sopko R, Andrews BJ. 2008. Linking the kinome and phosphorylome-A comprehensive review of approaches to find kinase targets. Mol Biosyst 4: 920-933.

Ståhl PL, Lundeberg J. 2012. Toward the single-hour high-quality genome. Annu Rev Biochem 81: 359-378.

Starai VJ, Takahashi H, Boeke JD, Escalante-Semerena JC. 2004. A link between transcription and intermediary metabolism: A role for Sir2 in the control of acetyl-coenzyme A synthetase. Curr Opin Microbiol 7: 115-119.

Stenkamp RE, Teller DC, Palczewski K. 2005. Rhodopsin: A structural primer for G-protein coupled receptors. Arch Pharm 338: 209-216.

Strebhardt K. 2010. Multifaceted polo-like kinases: Drug targets and antitargets for cancer therapy. Nat Rev Drug Discov 9: 643-660.

Stynen B, Tournu H, Tavernier J, Van Dijck P. 2012. Diversity in genetic in vivo methods for protein-protein interaction studies: From the yeast two-hybrid system to the mammalian split-luciferase system. Microbiol Mol Biol Rev 76: 331-382.

Tagliabracci VS, Xiao J, Dixon JE. 2013. Phosphorylation of substrates destined for secretion by the Fam 20 kinases. Biochem Soc Trans 41: $1061-1065$.

Tang X, Orlicky S, Mittag T, Csizmok V, Pawson T, Forman-Kay JD, Sicheri F, Tyers M. 2012. Composite low affinity interactions dictate recognition of the cyclin-dependent kinase inhibitor Sicl by the SCFCdc4 ubiquitin ligase. Proc Natl Acad Sci 109: 3287-3292.

Tarrant MK, Cole PA. 2009. The chemical biology of protein phosphorylation. Annu Rev Biochem 78: 797-825.

Tartaglia LA, Dembski M, Weng A, Deng N, Culpepper J, Devos R, Richards GJ, Campfield LA, Clark FT, Deeds J, et al. 1995. Identification and expression cloning of a leptin receptor, OB-R. Cell 83: $1263-$ 1271.

Thompson BJ. 2010. Developmental control of cell growth and division in Drosophila. Curr Opin Cell Biol 22: 788-794.

Thorner J. 2006. Signal transduction. In Landmark papers in yeast biology (ed. Linder P, et al.), pp. 193-210. Cold Spring Harbor Laboratory Press, Cold Spring Harbor, NY.

Tian X, Azpurua J, Hine C, Vaidya A, Myakishev-Rempel M, Ablaeva J, Mao Z, Nevo E, Gorbunova V, Seluanov A. 2013. High-molecularmass hyaluronan mediates the cancer resistance of the naked mole rat. Nature 499: 346-349.

Toettcher JE, Weiner OD, Lim WA. 2013. Using optogenetics to interrogate the dynamic control of signal transmission by the ras/erk module. Cell 155: 1422-1434.

Tong X, Shigetomi E, Looger LL, Khakh BS. 2013. Genetically encoded calcium indicators and astrocyte calcium microdomains. Neuroscientist 19: 274-291.

Tsien RY. 2009. Constructing and exploiting the fluorescent protein paintbox. Angew Chem Int Ed Engl 48: 5612-5626.

Turk BE, Cantley LC. 2003. Peptide libraries: At the crossroads of proteomics and bioinformatics. Curr Opin Chem Biol 7: 84-90.

Turk BE, Hutti JE, Cantley LC. 2006. Determining protein kinase substrate specificity by parallel solution-phase assay of large numbers of peptide substrates. Nat Protoc 1: 375-379.

Turner BM. 1991. Histone acetylation and control of gene expression. J Cell Sci 99: 13-20.

Urnov FD, Rebar EJ, Holmes MC, Zhang HS, Gregory PD. 2010. Genome editing with engineered zinc finger nucleases. Nat Rev Genet 11: 636-646.

Vadas O, Burke JE, Zhang X, Berndt A, Williams RL. 2011. Structural basis for activation and inhibition of class I phosphoinositide 3kinases. Sci Signal 4: re.2.1-re.2.12. 
Venta R, Valk E, Kõivomägi M, Loog M. 2012. Double-negative feedback between S-phase cyclin-CDK and CKI generates abruptness in the G1/ S switch. Front Physiol 3: 459.

Venter JC, Levy S, Stockwell T, Remington K, Halpern A. 2003. Massive parallelism, randomness and genomic advances. Nat Genet 33: 219227.

Vézina C, Kudelski A, Sehgal SN. 1975. Rapamycin (AY-22,989), a new antifungal antibiotic. I. Taxonomy of the producing streptomycete and isolation of the active principle. J Antibiot (Tokyo) 28: $721-726$.

Waksman G, Kominos D, Robertson SC, Pant N, Baltimore D, Birge RB, Cowburn D, Hanafusa H, Mayer BJ, Overduin M, et al. 1992. Crystal structure of the phosphotyrosine recognition domain $\mathrm{SH} 2$ of v-src complexed with tyrosine-phosphorylated peptides. Nature 358: 646-653.

Washietl S, Will S, Hendrix DA, Goff LA, Rinn JL, Berger B, Kellis M. 2012. Computational analysis of noncoding RNAs. Wiley Interdiscip Rev RNA 3: 759-778.

Wei C, Liu J, Yu Z, Zhang B, Gao G, Jiao R. 2013. TALEN or Cas9-Rapid, efficient and specific choices for genome modifications. J Genet Genomics 40: 281-289.

Weston CR, Davis RJ. 2001. Signaling specificity-A complex affair. Science 292: 2439-2440.

Wong SY, Reiter JF. 2008. The primary cilium at the crossroads of mammalian hedgehog signaling. Curr Top Dev Biol 85: 225-260.

Woodward JJ, Iavarone AT, Portnoy DA. 2010. c-di-AMP secreted by intracellular Listeria monocytogenes activates a host type I interferon response. Science 328: 1703-1705.

Wu H. 2013. Higher-order assemblies in a new paradigm of signal transduction. Cell 153: 287-292.

Wu H, Zhang Y. 2011. Mechanisms and functions of Tet protein-mediated 5-methylcytosine oxidation. Genes Dev 25: 2436-2452.
Xiao H, Chatterjee A, Choi SH, Bajjuri KM, Sinha SC, Schultz PG. 2013a. Genetic incorporation of multiple unnatural amino acids into proteins in mammalian cells. Angew Chem Int Ed Engl 52: 14080-14083.

Xiao J, Tagliabracci VS, Wen J, Kim SA, Dixon JE. 2013b. Crystal structure of the Golgi casein kinase. Proc Natl Acad Sci 110: 10574-10579.

Xu J, Wang AH, Oses-Prieto J, Makhijani K, Katsuno Y, Pei M, Yan L, Zheng YG, Burlingame A, Brückner K, et al. 2013. Arginine methylation initiates BMP-induced Smad signaling. Mol Cell 51: 5-19.

Yang W, Xia Y, Hawke D, Li X, Liang J, Xing D, Aldape K, Hunter T, Alfred Yung WK, Lu Z. 2012. PKM2 phosphorylates histone H3 and promotes gene transcription and tumorigenesis. Cell 150: 685-696.

Zacharias DA, Tsien RY. 2006. Molecular biology and mutation of green fluorescent protein. Methods Biochem Anal 47: 83-120.

Zhang Z, Tan M, Xie Z, Dai L, Chen Y, Zhao T. 2011. Identification of lysine succinylation as a new post-translational modification. Nat Chem Biol 7: 58-63.

Zhang M, Galdieri L, Vancura A. 2013. The yeast AMPK homolog SNF1 regulates acetyl coenzyme A homeostasis and histone acetylation. $\mathrm{Mol}$ Cell Biol 33: 4701-4717.

Zhou X, Herbst-Robinson KJ, Zhang J. 2012. Visualizing dynamic activities of signaling enzymes using genetically encodable FRET-based biosensors from designs to applications. Methods Enzymol 504: 317-340.

Zimmermann H. 2008. ATP and acetylcholine, equal brethren. Neurochem Int 52: 634-648.

Zivanovic N, Jacobs A, Bodenmiller B. 2013. A practical guide to multiplexed mass cytometry. Curr Top Microbiol Immunol doi: 10.1007/ 82_2013_335.

Zmajkovicova K, Jesenberger V, Catalanotti F, Baumgartner C, Reyes G, Baccarini M. 2013. MEK1 is required for PTEN membrane recruitment, AKT regulation, and the maintenance of peripheral tolerance. Mol Cell 50: 43-55. 


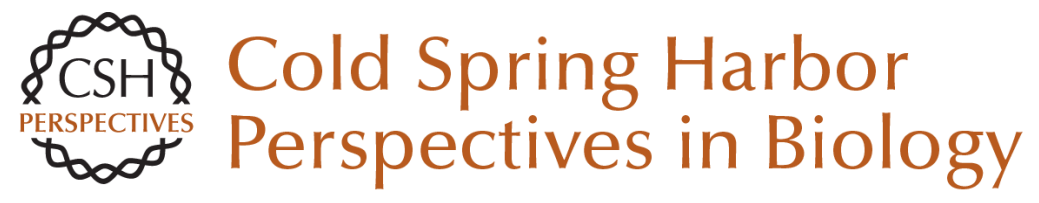

\section{Signal Transduction: From the Atomic Age to the Post-Genomic Era}

Jeremy Thorner, Tony Hunter, Lewis C. Cantley and Richard Sever

Cold Spring Harb Perspect Biol 2014; doi: 10.1101/cshperspect.a022913 originally published online October 30, 2014

\section{Subject Collection Signal Transduction}

Cell Signaling and Stress Responses Gökhan S. Hotamisligil and Roger J. Davis

Protein Regulation in Signal Transduction Michael J. Lee and Michael B. Yaffe

Synaptic Signaling in Learning and Memory Mary B. Kennedy

Vertebrate Reproduction Sally Kornbluth and Rafael Fissore

Signaling in Lymphocyte Activation Doreen Cantrell

Signaling in Muscle Contraction Ivana Y. Kuo and Barbara E. Ehrlich

Toll-Like Receptor Signaling Kian-Huat Lim and Louis M. Staudt

Signaling Pathways that Regulate Cell Division Nicholas Rhind and Paul Russell
Second Messengers

Alexandra C. Newton, Martin D. Bootman and John D. Scott

Signals and Receptors Carl-Henrik Heldin, Benson Lu, Ron Evans, et al.

Cell Death Signaling Douglas $R$. Green and Fabien Llambi

Signaling Networks that Regulate Cell Migration Peter Devreotes and Alan Rick Horwitz

Signaling Networks: Information Flow, Computation, and Decision Making Evren U. Azeloglu and Ravi lyengar

Signal Transduction: From the Atomic Age to the Post-Genomic Era Jeremy Thorner, Tony Hunter, Lewis C. Cantley, et al.

Signaling by the TGF $\beta$ Superfamily Jeffrey L. Wrana

Subversion of Cell Signaling by Pathogens Neal M. Alto and Kim Orth

For additional articles in this collection, see http://cshperspectives.cshlp.org/cgi/collection/

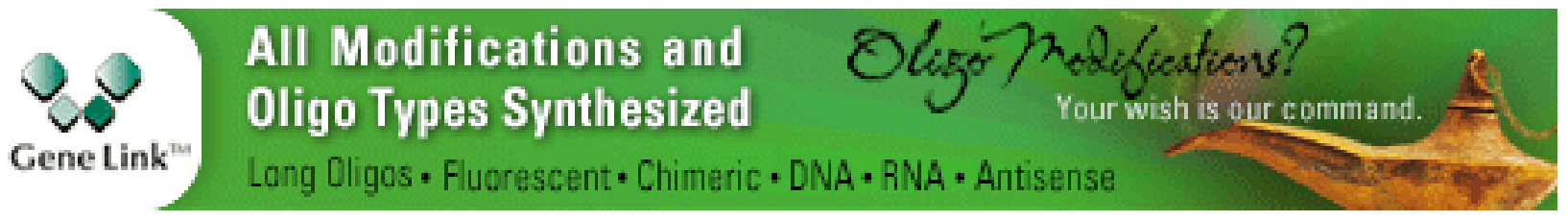

Copyright (C 2014 Cold Spring Harbor Laboratory Press; all rights reserved 